Supplement of Earth Syst. Dynam., 11, 357-376, 2020

https://doi.org/10.5194/esd-11-357-2020-supplement

(C) Author(s) 2020. This work is distributed under

the Creative Commons Attribution 4.0 License.

(c) (1)
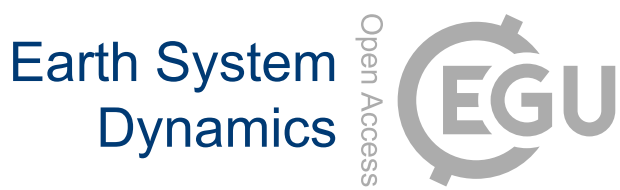

Supplement of

\title{
Impacts of future agricultural change on ecosystem service indicators
}

Sam S. Rabin et al.

Correspondence to: Sam S. Rabin (sam.rabin@kit.edu)

The copyright of individual parts of the supplement might differ from the CC BY 4.0 License. 


\section{S1 LPJ-GUESS run setup}

This section provides further details and rationale for the types of model runs used in LandSyMM (summarized in Table S1). Figure S1 gives an overview of how information flows between the different runs. Tables S3-S6 describe the input data used for each run type.

LPJ-GUESS simulates only four crop functional types (CFTs): spring wheat, winter wheat, maize, and rice. These must be translated to the seven PLUM crop types, as described in Section S2. This process uses crop-specific values called calibration factors. In this study, the "calibration" was used in generating these calibration factors, with mostly the same methodology detailed in Alexander et al. (2018). However, in that previous work, only four crop stand types were simulated in LPJ-GUESS, corresponding to the four LPJ-GUESS CFTs (Alexander et al., 2018). This meant that starchy roots, oilcrops, and pulses all received the same management inputs (i.e., fertilizer and irrigation). In the work presented here, we have separated these three into distinct stand types that all use the TeSW CFT but with different management inputs based on crop-specific historical datasets (Table S8). This change results in different calibration factors being used here than in Alexander et al. (2018); the new calibration factors can be found in Fig. S3.

The calibration run was forced with "CRU-NCEP v7 CRUp" climate data (Table S3), which use forcings from CRU-NCEP version 7 (Le Quéré et al., 2016; Viovy, 2016, ${ }^{1}$ ) except with CRU TS3.24 precipitation (Harris et al., 2014) due to problems discovered in the CRU-NCEP precipitation data. $^{2}$ The MIRCA2000 dataset (Portmann et al., 2010) provided crop type distributions for the year 2000, which were used for all historical years in the calibration run. Some mapping between MIRCA, LPJ-GUESS, and PLUM crop types was required, details of which can be found in Section SM2. Fertilizer application for the calibration run was taken from the dataset prepared for the Global Gridded Crop Model Intercomparison exercise (Elliott et al., 2015) of the Agricultural Model Intercomparison Project (AgMIP; Rosenzweig et al., 2013). In the historical period of other runs, nitrogen fertilizer application rates were taken from LUH2 (Hurtt et al., in prep). Manure $\mathrm{N}$ was added in the historical period according to the annually-varying maps given in Zhang et al. (2017b), but in the calibration run was held constant at year 2000 levels to match the use of the AgMIP fertilizer data. Simulation years outside the dataset's 1860-2014 range used 1860 and 2014 values, respectively.

A set of "yield-generating" experiments were then performed to produce potential crop yields and pasture grass production for input to PLUM. These consist of two phases: an initial and an alternating phase. The initial phase runs from 1850 to 2000, and is intended to reproduce historical land uses and crop yields in a way that is consistent with previously developed land-use histories. Historical land use areas, irrigation, and synthetic nitrogen fertilizer application levels were taken from the Land Use Harmonization v2 dataset (LUH2; Hurtt et al., in prep.). Historical manure application rates (simplified upon import to LPJ-GUESS as pure nitrogen addition) come from Zhang et al. (2017b).

The alternating phase, which begins in 2001, iterates between "potential runs" and "actual runs," the latter of which exist only to provide initial soil conditions to the potential runs (Fig. S1). In the potential runs, the non-barren land in every gridcell is converted to $50 \%$ cropland and $50 \%$ pasture, with homogenized soil based on the state after the previous actual run (Fig. S1; Table S5). Cropland is subdivided into 36 equally-sized stands in a factorial experiment with the six crop stand types (excluding Miscanthus), three nitrogen fertilizer treatments $\left(0,200\right.$, and $1000 \mathrm{kgN} \mathrm{ha}^{-1} \mathrm{yr}^{-1}$, and two irrigation treatments (rainfed or fully irrigated). Potential runs begin every five years, with each lasting ten years. Only the last five years' yields are passed to PLUM, with the first five years being used to give LPJ-GUESS time to spin up crop phenological parameters. Thus, for example, the potential run covering 2006-2015 generates output for 2011-2015, which is used in PLUM to determine land uses and managements for 20162020 (Fig. S1). Actual runs each last five years, with the land system state being saved after each for input to the potential runs. Land use and management in the actual runs uses LUH2

\footnotetext{
${ }^{1}$ http://dods.extra.cea.fr/store/p529viov/cruncep/V7_1901_2015, accessed 30 June 2016

${ }^{2}$ The CRU-NCEP algorithm was designed to match CRU TS3.24 monthly precipitation totals, but it produced unrealistically high numbers of wet daysdays with precipitation of at least $0.1 \mathrm{~mm}$-in the tropics and boreal regions in the early part of the 20th century.
} 


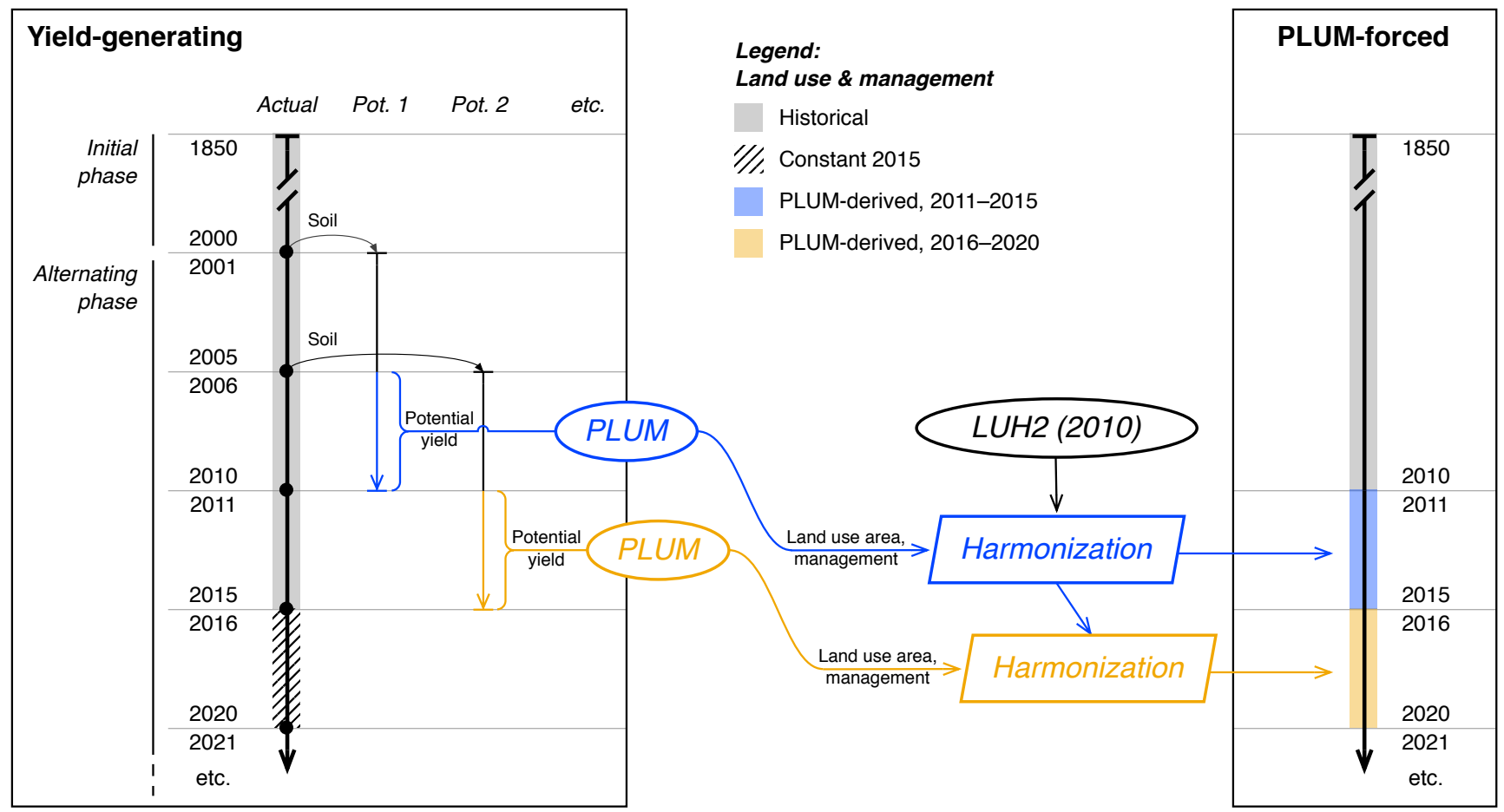

Figure S1. Information flow between LPJ-GUESS and PLUM. Historical land use and management is time-varying for land use fractions through 2015 but constant for crop mix, fertilizer application, and per-crop irrigated fraction (see Sect. 3.3.1). Adapted from Figure SI-1 in Alexander et al. (2018).

data through 2015, after which values are held constant (Table S4).

All "yield-generating" runs used the atmospheric $\mathrm{CO}_{2}$ concentrations and climate forcings from the Fifth Coupled Model Intercomparison Project (CMIP5; Taylor et al., 2012): specifically, the IPSL-CM5A-MR forcings (Dufresne et al., 2013), which were bias-corrected (Ahlström et al., 2012) to the 1961-1990 observation-based climate used by the calibration runs (Tables S4, S5). Because not all SSP-RCP combinations are equally plausible, the PLUM-forced runs used future climate forcings corresponding to the most likely RCP for each SSP, based on the SSP-RCP probability matrix from Engström et al. (2016): i.e., RCP4.5 for SSP1, RCP6.0 for SSP3 and SSP4, and RCP8.5 for SSP5. Three instances of the yieldgenerating runs were performed: one with each of the RCP climate scenarios.

Finally, the "PLUM-forced" runs combined the PLUM outputs of land use areas and management (harmonized as de- scribed in Sects. 2.3 and S3) with the same climate and atmospheric $\mathrm{CO}_{2}$ concentrations used in the yield-generating runs.

All runs are preceded by a 500-year spinup period using a temperature-detrended version of the relevant climate forcings (CRU-NCEP v7 CRUp for the calibration run; IPSLCM5A-MR for the yield-generating and PLUM-forced historical runs.) This includes a routine that analytically solves for equilibrium soil carbon content, bringing carbon pools into equilibrium before the beginning of the actual run.

\section{S2 Mapping of MIRCA, LPJ-GUESS, and PLUM crop types}

MIRCA crop types are mapped to the LPJ-GUESS crop stand types as described in Table S8. Some MIRCA categories were excluded: sugarcane, citrus, date palm, grapes/vine, cotton, cocoa, coffee, other annuals, other perennials, and fodder grasses. A dummy crop type, ExtraCrop, was created to partition this unmapped fraction of cropland away from cropland 
Table S1. Guide to the runs performed.

\begin{tabular}{|c|c|c|c|}
\hline Run name & Years & Purpose & Number \\
\hline Calibration & 1901-2005 & $\begin{array}{l}\text { Simulate } 1995-2005 \text { crop yields for } \\
\text { calibrating against FAOSTAT data. }\end{array}$ & 1 \\
\hline $\begin{array}{l}\text { Yield-generating, } \\
\text { actual }\end{array}$ & $1850-2100$ & $\begin{array}{l}\text { 1850-2010: Historical simulation for } \\
\text { comparison with PLUM-forced future runs. } \\
\text { All: Provide soil state for yield-generating } \\
\text { potential runs. }\end{array}$ & $\begin{array}{l}\text { 1850-2010: } 1 \\
\text { 2011-2100: } 4 \text { (SSP-RCP } \\
\text { combinations) }\end{array}$ \\
\hline $\begin{array}{l}\text { Yield-generating, } \\
\text { potential }\end{array}$ & $1850-2100$ & $\begin{array}{l}\text { Generate potential yield for each crop type } \\
\text { under different fertilization and irrigation } \\
\text { treatments, for use in PLUM. }\end{array}$ & $\begin{array}{l}\text { 1850-2010: } 1 \\
\text { 2011-2100: } 4 \text { (SSP-RCP } \\
\text { combinations) }\end{array}$ \\
\hline PLUM-forced & 2011-2100 & $\begin{array}{l}\text { Simulate terrestrial vegetation and } \\
\text { ecosystem service indicators under } \\
\text { land-use and -management trajectories } \\
\text { specified by PLUM. }\end{array}$ & $\begin{array}{l}\text { 25: sXlum_rYYclico2, } \\
\text { sXlum*(4 PLUM outputs), } \\
(\text { rYYClico2 + rYYCO2 }+ \\
\text { rYYCli)*(3 RCPs), } \\
(\text { sXlum_rYYCO2 + } \\
\text { sXlum_rYYCli)*(4 SSP-RCP } \\
\text { combinations) }\end{array}$ \\
\hline
\end{tabular}

considered in PLUM. Additionally, $10.3 \%$ of mapped crop types were moved to ExtraCrop, corresponding to the cropland fraction not harvested due, e.g., to crop failures or fallow periods (FAOSTAT, 2018c, b). In all, approximately $38 \%$ of cropland was in ExtraCrop over 2001-2010. LPJ-GUESS plants ExtraCrop, which receives no irrigation or fertilizer, with either winter wheat (TeWW) or spring wheat (TeSW) based on sowing constraints derived from long-term climate history in each gridcell. By not applying management inputs to ExtraCrop, we likely underestimate the effects of future land use and management changes on water use and nitrogen losses in absolute terms; however, this allows us to focus solely on the ecosystem services impacts of the crops explicitly included in PLUM.

To generate yields of a crop not included in LPJ-GUESS (e.g., oilcrops), a separate stand is simulated and planted with spring wheat, and a calibration factor then later multiplied onto the resulting yields to generate a wider range of crop yields as input to PLUM (Table S8). (For consistency, calibration factors are also used for crops such as rice that are included in both LPJ-GUESS and PLUM.) These calibration factors are derived from a comparison of the LPJ-GUESS simulated yields with the crop yields reported in the FAOSTAT database (FAOSTAT, 2018c, a). A historical "calibration run" from 1901-2005 was used to generate gridded yields for 1995-2005; these were aggregated to the country level, with simulated country-year data points being regressed (with
Y-intercept set to zero) against the values derived from FAOSTAT.

\section{S3 Harmonization of future and historical land use data}

The harmonization code (Rabin, 2019) is based on the code published for LUH1 (Hurtt et al., 2011, http://luh.umd.edu/code.shtml), but extended to harmonize the area of pasture and each crop rather than just pasture and cropland. It begins with land use from LUH2 in 2010, with cropland subdivided based on MIRCA as described in Section S1, then attempts to apply changes (deltas) in land use area between PLUM's 2010 and 2011 outputs. Grid cells can reach limits: The deltas might specify loss of cropland when the grid cell is already $0 \%$ cropland, or likewise the deltas might specify expansion of cropland when it's already $100 \%$ cropland. In such cases, the algorithm looks for space to apply the remaining "unmet" deltas in the grid cells bordering the cell in question. It expands the radius of this search until all deltas are satisfied. This process is repeated for every cell with unmet deltas. Once complete, the algorithm moves on to the next year: The PLUM changes for 2011-2012 are applied to the harmonized 2011 land use map, and so on.

Our algorithm has another feature not present in the LUH1 harmonization, which is to harmonize fertilizer and irrigation (the latter in arbitrary units of intensity*area). The way it does this is analogous to how it treats land use area. Limits for irri- 
gation in a cell are 0 and 1 . The lower limit for fertilizer for any given crop is also zero, but the upper limit varies. It is either the maximum seen for the crop in any gridcell in any PLUM output thus far (i.e., if we're working on deltas for 2020-2021, consider PLUM outputs from 2021 and before), or in LUH2 during or before the base year (here, 2010), or in any harmonized output thus far (although, because of the first two rules, this should never come into play).

Technical details on other differences between the LUH1 method and our algorithm, as well as our harmonization code itself, are available on GitHub (Rabin, 2019).

While harmonization preserves global area totals, our implementation greatly increases the area of land experiencing land use change (Fig. S2). This behavior stems from our version working on area of specific crops, not just (as the LUH1 harmonization did) on total cropland area. If we collapse all crops into one type, gross land use changes are barely affected by harmonization (Table S2).

Why does this happen? Consider a gridcell that, in 2011, PLUM tells to lose $100 \mathrm{~km}^{2}$ of rice. If not considering individual crops, PLUM's land use map for 2010 would only have had to match the historical data in terms of total cropland area. But in our implementation, they need to agree on rice area specifically. Per-crop harmonization thus increases the probability of disagreement between PLUM and the historical data for land use area in 2010, thereby increasing the probability that the harmonization needs to make up the difference in another gridcell.

Although our harmonization procedure is based on a wellregarded algorithm, the discrepancies introduced by considering separate crop types complicate interpretation of results. In a gridcell that experiences land-use change only after harmo- nization, impacts on ecosystem services may have been displaced from where PLUM anticipated that land-use change to occur. The extent to which overall regional and global scale ecosystem service provision is affected by the disagreement between the historical data and PLUM in 2010 will depend on whether the land-use change is coming from a cell of similar biome, land-use history, etc. Increasing the amount of land experiencing land-use transitions also decreases mean ecosystem age, with potential implications for carbon storage and ecosystem function.

Where necessary, in our results we note geographic patterns that may have been more a result of the harmonization process than PLUM-specified land-use change. However, reducing the impacts of harmonization on land use area and management maps would allow a more direct interpretation, with fewer confounding factors, of how changing demand, climate, and technology affect ecosystem services. Given the inherent complexities of modelling human societies, harmonization is likely to remain a fundamental component of such investigations for the foreseeable future; as such, further development of our algorithm will aim to minimize harmonization effects.

Table S2. Harmonization-induced change in 2010-2100 gross gain and loss of non-agricultural area.

\begin{tabular}{l|ll|ll}
\hline & \multicolumn{2}{|c|}{ As described } & \multicolumn{2}{c}{ Combined crops } \\
Scenario & $\Delta$ gain & $\Delta$ loss & $\Delta$ gain & $\Delta$ loss \\
\hline SSP1-45 & $+275 \%$ & $+124 \%$ & $+7 \%$ & $+3 \%$ \\
SSP3-60 & $+25 \%$ & $+168 \%$ & $+2 \%$ & $<+0.5 \%$ \\
SSP4-60 & $+159 \%$ & $+39 \%$ & $-1 \%$ & $<-0.5 \%$ \\
SSP5-85 & $+126 \%$ & $+36 \%$ & $+1 \%$ & $<+0.5 \%$ \\
\hline
\end{tabular}

Table S3. Input data used for each portion of calibration run. Zhang et al. (2017a) manure data extended as specified in Methods.

\begin{tabular}{|c|c|c|c|c|c|}
\hline Years & Climate & LU & Crop fractions & Fert. & Irrig. \\
\hline $1850-1900$ & - & - & - & - & - \\
\hline $2006-2010$ & - & - & - & - & - \\
\hline $2011-2015$ & - & - & - & - & - \\
\hline $2016-2100$ & - & - & - & - & - \\
\hline
\end{tabular}

-: Time period not simulated in given run.

DATASET @YYYY: Using value from DATASET at year YYYY

*: Irrigation specified by fraction of crop fully rainfed or fully irrigated. 


\section{Original $\Delta$ NATURAL, 2010-2100}

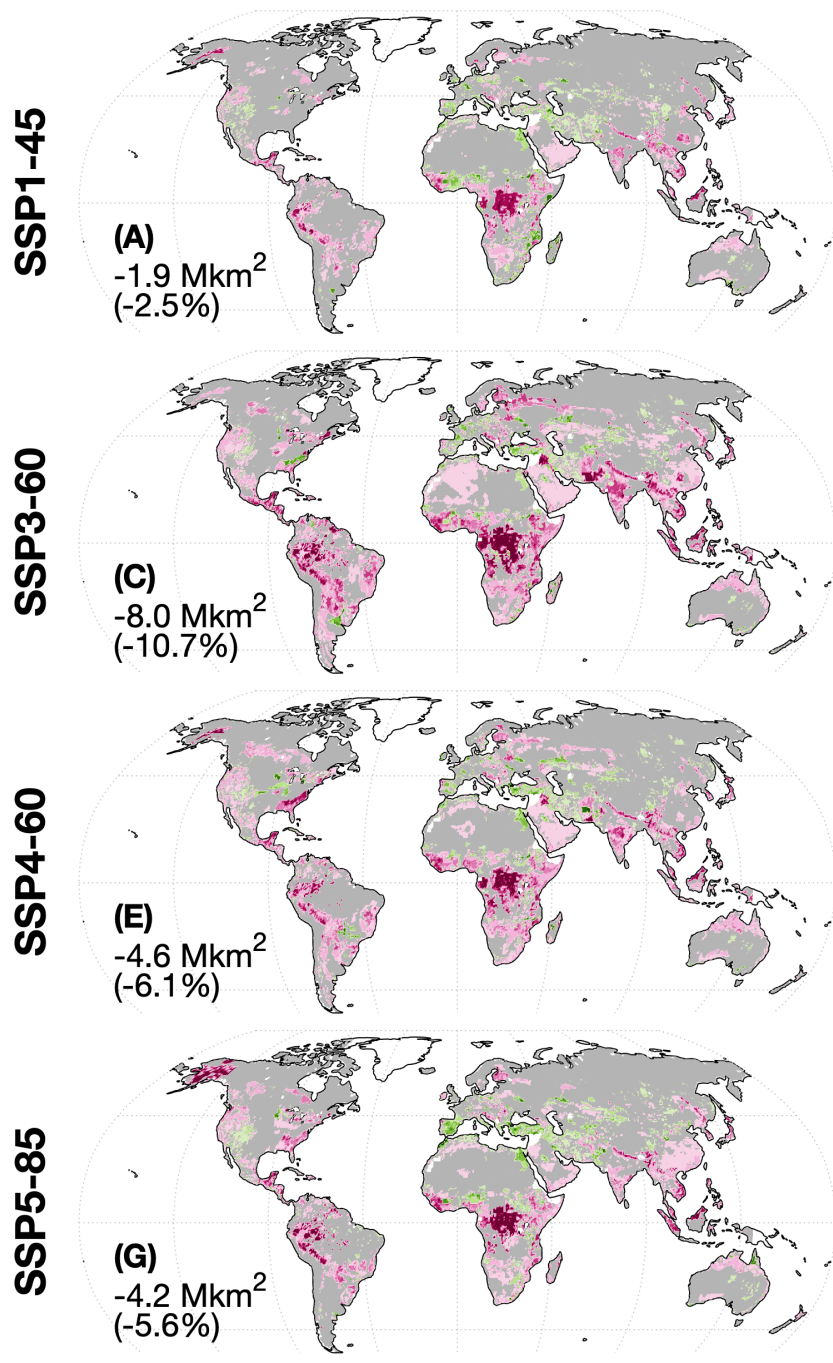

\section{Harmonized $\Delta$ NATURAL, 2010-2100}
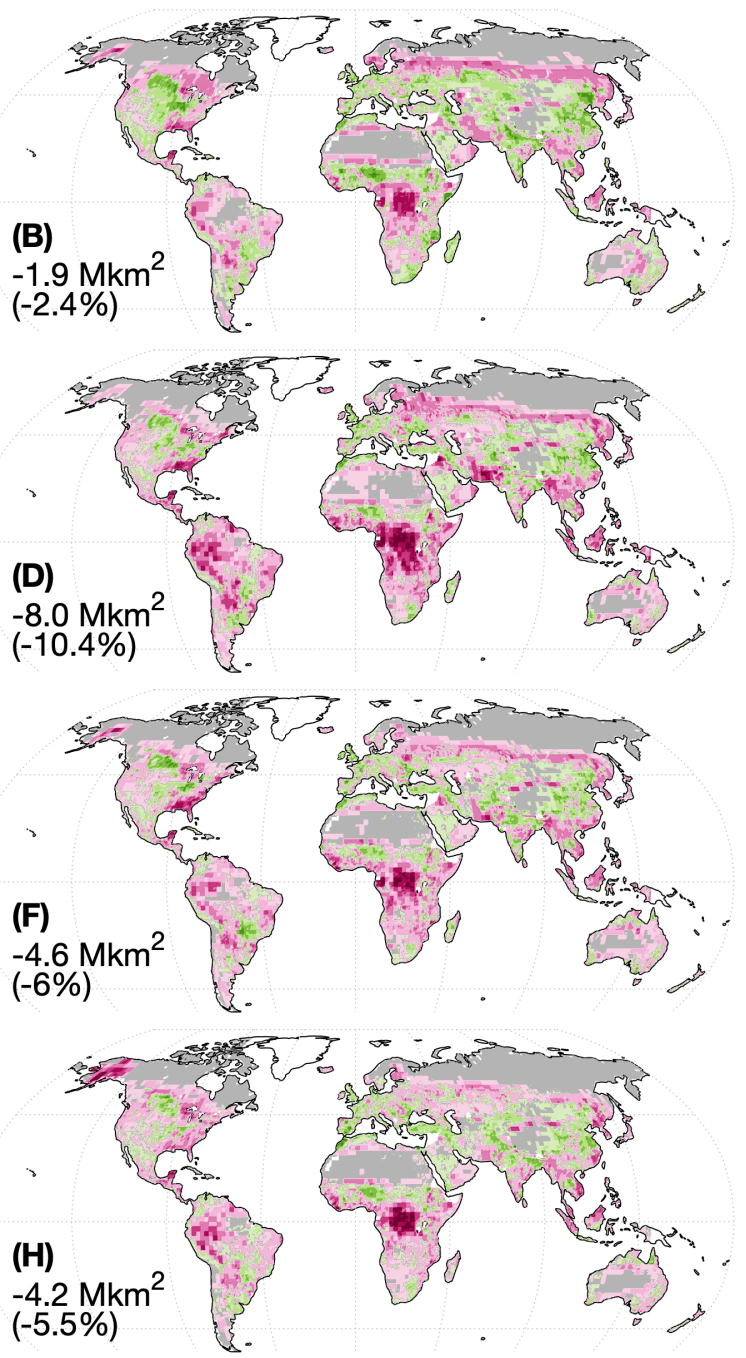

$$
-100-80-60-40 \quad-20 \quad-5 \quad-0.1+0.1+5+20+40+60+80+100 \quad(\%)
$$

Figure S2. Change in non-agricultural land area (as fraction of gridcell) over 2010-2100 from raw PLUM outputs (left column) and after harmonization (right column) for each scenario (rows). Inconsistencies in relative net global change (percentages) are due to different baseline (2010) land use area maps between the two columns. 
Table S4. Input data used for each portion of "actual" yield-generating runs. Zhang et al. (2017a) manure data extended as specified in Methods.

\begin{tabular}{|c|c|c|c|c|c|}
\hline Years & Climate & LU & Crop fractions & Fert. & Irrig. \\
\hline $1850-1900$ & $\begin{array}{l}\text { CMIP5 } \\
\text { IPSL-CM5A-MR }\end{array}$ & LUH2 & MIRCA @2000 & LUH2 + Zhang et al. & LUH2* \\
\hline $1901-2005$ & $\downarrow$ & $\downarrow$ & $\downarrow$ & $\downarrow$ & $\downarrow$ \\
\hline $2006-2010$ & $\downarrow$ & $\downarrow$ & $\downarrow$ & $\downarrow$ & $\downarrow$ \\
\hline $2011-2015$ & $\downarrow$ & $\downarrow$ & $\downarrow$ & $\downarrow$ & $\downarrow$ \\
\hline $2016-2100$ & $\downarrow$ & $\begin{array}{l}\text { LUH2 } \\
\text { @ } 2015\end{array}$ & $\downarrow$ & $\begin{array}{l}\text { LUH2 @ } 2015 \text { + Zhang } \\
\text { et al. @2015 }\end{array}$ & $\downarrow$ \\
\hline
\end{tabular}

DATASET @ YYYY: Using value from DATASET at year YYYY.

*: Irrigation specified by fraction of crop fully rainfed or fully irrigated.

Table S5. Input data used for each portion of "potential" yield-generating runs.

\begin{tabular}{llllll}
\hline Years & Climate & LU & Crop fractions & Fert. & Irrig. \\
\hline $1850-1900$ & - & - & - & - & - \\
\hline $1901-2005$ & - & - & - & - & - \\
\hline \multirow{2}{*}{$2006-2010$} & CMIP5 & Ice/water from LUH2; & Even crop $\times$ fertilizer $\times$ & 0,200, or 1000 & Rainfed or \\
& IPSL- & vegetated 50-50 & irrigation factorial & kgN ha $^{-1}$ & $\downarrow$ \\
& CM5A-MR & cropland and pasture & stands & $\downarrow$ \\
\hline $2011-2015$ & $\downarrow$ & $\downarrow$ & $\downarrow$ & $\downarrow$ & $\downarrow$ \\
\hline $216-2100$ & $\downarrow$ & $\downarrow$ & $\downarrow$ & $\downarrow$ & $\downarrow$ \\
\hline
\end{tabular}

-: Time period not simulated in given run.

Table S6. Input data used for each portion of PLUM-forced runs. Zhang et al. (2017a) manure data extended as specified in Methods.

\begin{tabular}{llllll}
\hline Years & Climate & LU & Crop fractions & Fert. & Irrig. \\
\hline \multirow{2}{*}{$1850-1900$} & CMIP5 & LUH2 & MIRCA @ 2000 & LUH2 + Zhang et al. & MIRCA @ 2000* \\
& IPSL-CM5A-MR & $\downarrow$ & $\downarrow$ & $\downarrow$ & $\downarrow$ \\
\hline $1901-2005$ & $\downarrow$ & $\downarrow$ & $\downarrow$ & $\downarrow$ & $\downarrow$ \\
\hline $2006-2010$ & $\downarrow$ & PLUM & PLUM & PLUM & PLUM $\dagger$ \\
\hline $2011-2015$ & $\downarrow$ & PLUM & PLUM & PLUM & PLUM $\dagger$ \\
\hline
\end{tabular}

DATASET @YYYY: Using value from DATASET at year YYYY.

*: Irrigation specified by fraction of crop fully rainfed or fully irrigated.

$\dagger$ : irrigation specified as fraction of maximum irrigation demand fulfilled. 
Table S7. Parameters used in PLUM. For more information, see Alexander et al. (2018) main text and supplement.

\begin{tabular}{|c|c|c|c|c|}
\hline Parameter & SSP1 & SSP3 & SSP4 & SSP5 \\
\hline Irrigation cost, $w_{\text {cost }}\left(\mathrm{USD} \mathrm{m}^{-2}\right)$ & 0.000440 & 0.000232 & 0.000350 & 0.000232 \\
\hline Fertilizer cost, $f_{\text {cost }}\left(\mathrm{USD} \mathrm{t}^{-1}\right)$ & 2.2 & 1.5 & 1.8 & 1.1 \\
\hline $\begin{array}{l}\text { Other intensity cost, } m_{\text {cost }} \text { (USD at } \\
\text { max management input) }\end{array}$ & 0.8 & 0.7 & 0.7 & 0.6 \\
\hline $\begin{array}{l}\text { Land cover change cost, } l c_{\text {change: }} \\
\text { Natural to agricultural }\left(\mathrm{USD} \mathrm{ha}^{-1}\right)\end{array}$ & 107 & 31 & 54 & 38 \\
\hline $\begin{array}{l}\text { Land cover change cost, } l c_{\text {change }} \text { : } \\
\left.\text { Pasture to cropland (USD ha }{ }^{-1}\right)\end{array}$ & 290 & 205 & 232 & 161 \\
\hline $\begin{array}{l}\text { Land cover change cost, } l c_{\text {change: }} \\
\left.\text { Cropland to pasture (USD ha }{ }^{-1}\right)\end{array}$ & 575 & 366 & 432 & 300 \\
\hline $\begin{array}{l}\text { Minimum natural or managed forest } \\
\text { cover }\end{array}$ & $19.5 \%$ & $4.5 \%$ & $6.2 \%$ & $4.5 \%$ \\
\hline $\begin{array}{l}\text { Technology yield change rate, } \delta \text {, above } \\
\text { that from intensification of production }\end{array}$ & $0.44 \%$ & $0.00 \%$ & $0.20 \%$ & $0.30 \%$ \\
\hline International market price sensitivity, $\lambda$ & 0.4 & 0.4 & 0.4 & 0.4 \\
\hline International import tariff, $i_{\text {tariff }}$ & $-20 \%$ & $43 \%$ & $19 \%$ & $-36 \%$ \\
\hline Transport costs, $t_{\text {cost }}\left(\mathrm{USD} \mathrm{t}^{-1}\right)$ & 63 & 43 & 57 & 37 \\
\hline Annual change in imports allowed & $2.2 \%$ & $1.4 \%$ & $1.7 \%$ & $2.6 \%$ \\
\hline
\end{tabular}




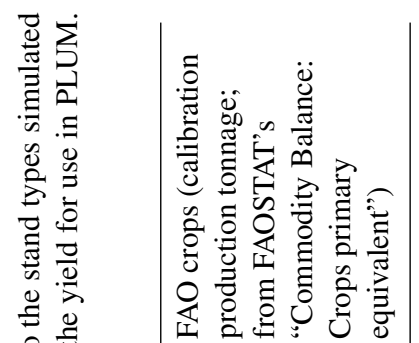

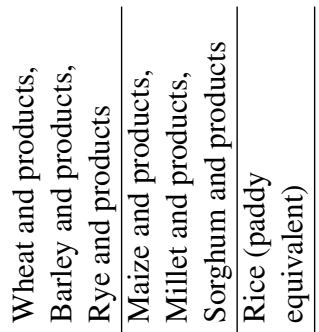

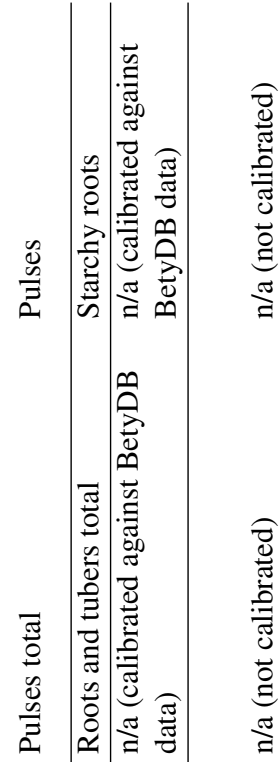

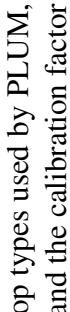

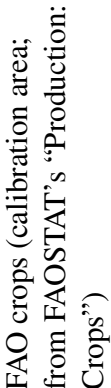

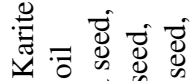

递

要离

s.

$\sum_{000}^{\infty}$

言

8

药

要

音曾

要

焉

政:

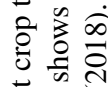

僖言

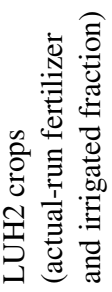

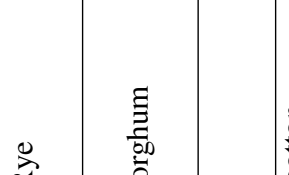

$\frac{\tilde{0}}{\tilde{0}}$

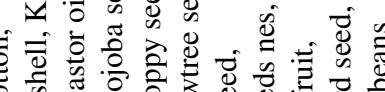

$\approx$ व

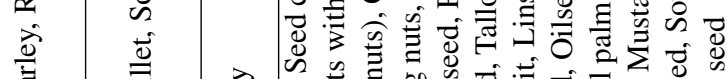

焉

芯这

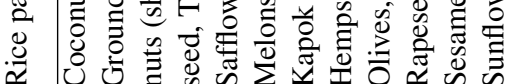

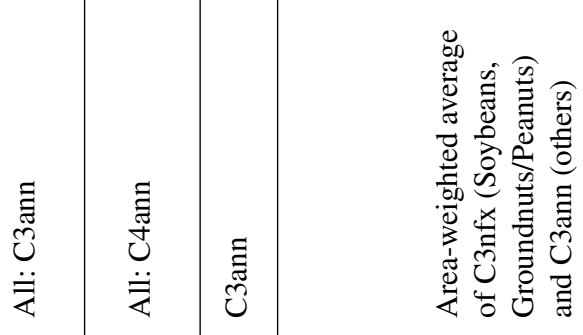

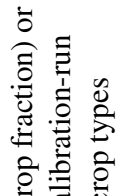

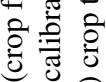

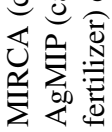

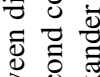

居

on

育㲅

政

$\infty$ 엉

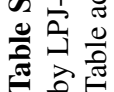
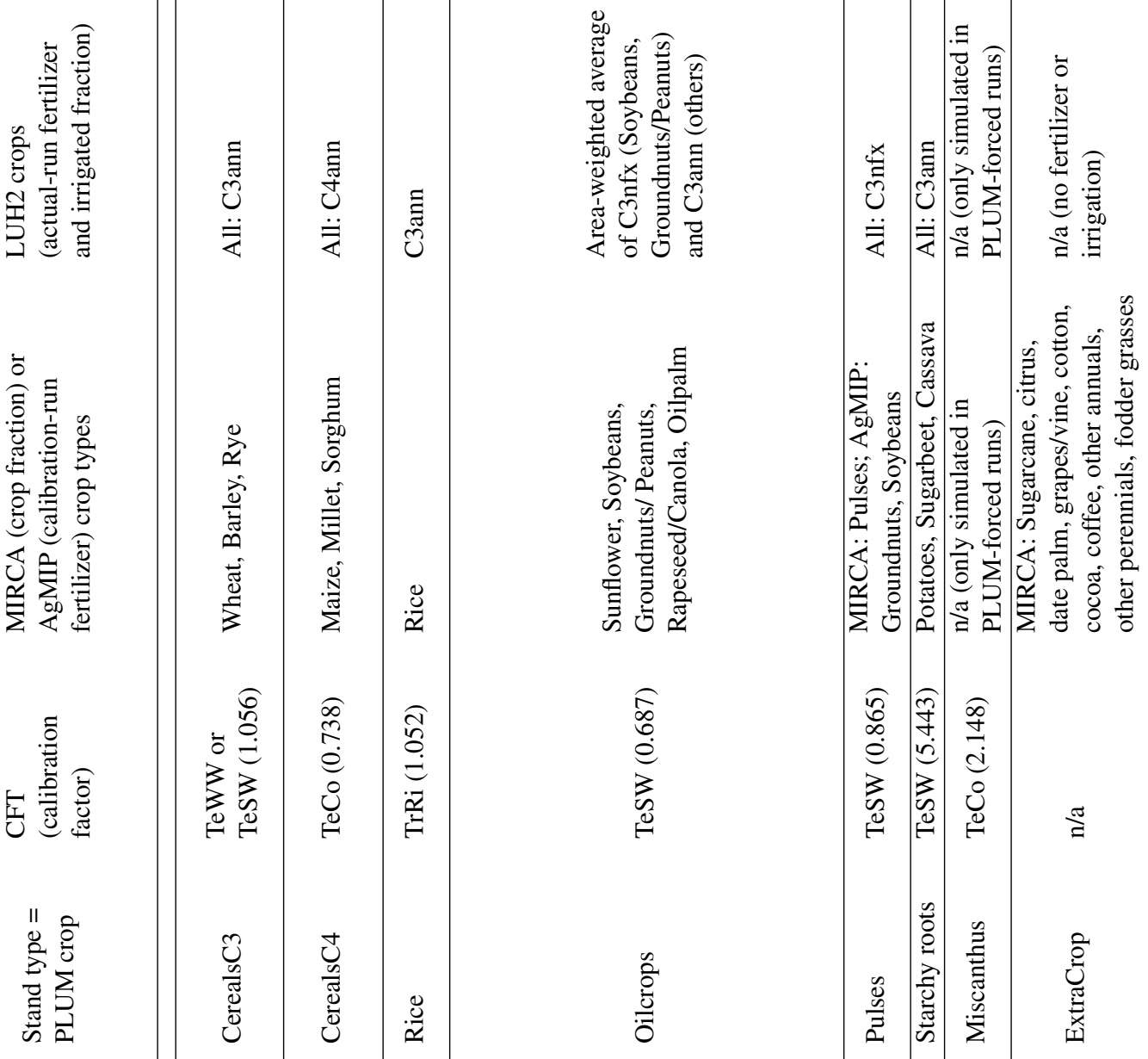

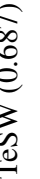

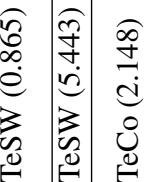

औ

商

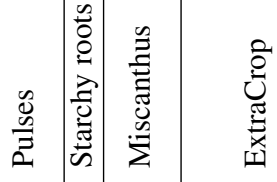



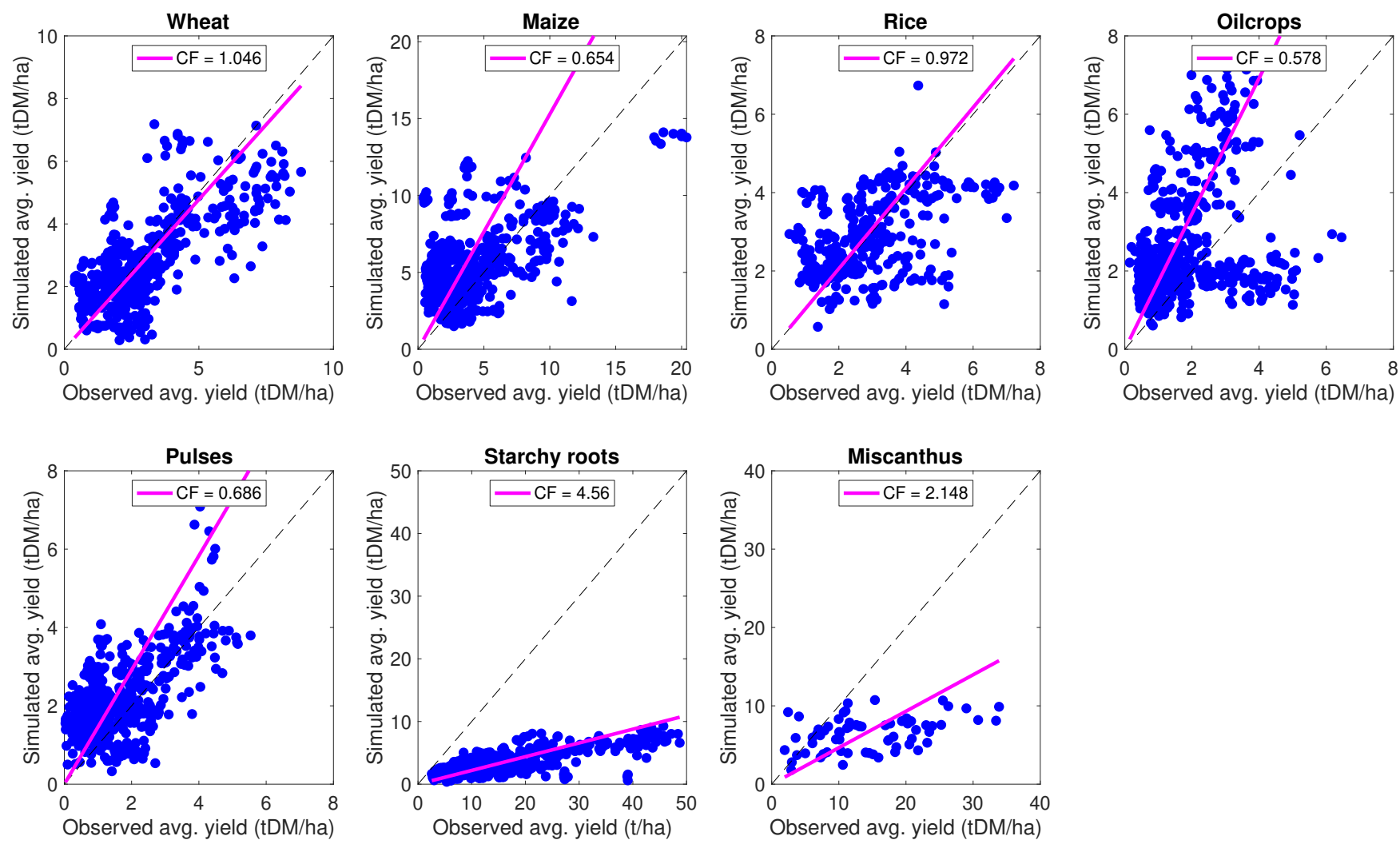

Figure S3. Scatter plots between observed and LPJ-GUESS yield, with regression line used to determine calibration factors. Each point represents one country's yield in a single year. Corresponds to Fig. SI-2 in Alexander et al. (2018). 


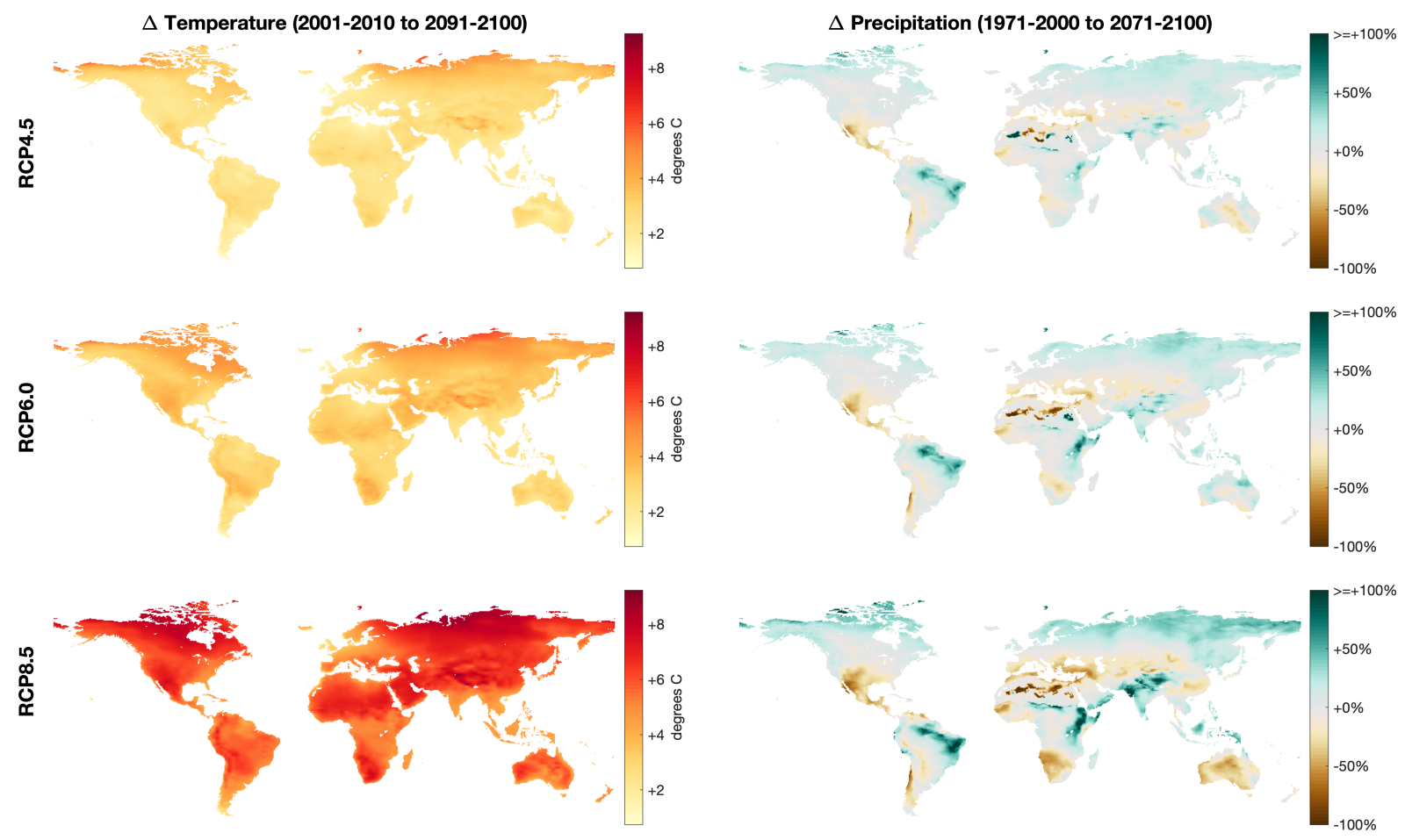

Figure S4. Change in mean global temperature (degrees Celsius; left column) and precipitation (percent, right column) between historical and future periods for each RCP (rows). Temperature given as bias-corrected by LPJ-GUESS. 30 years used for precipitation because of high interannual variability, consistent with main text Fig. 2 .
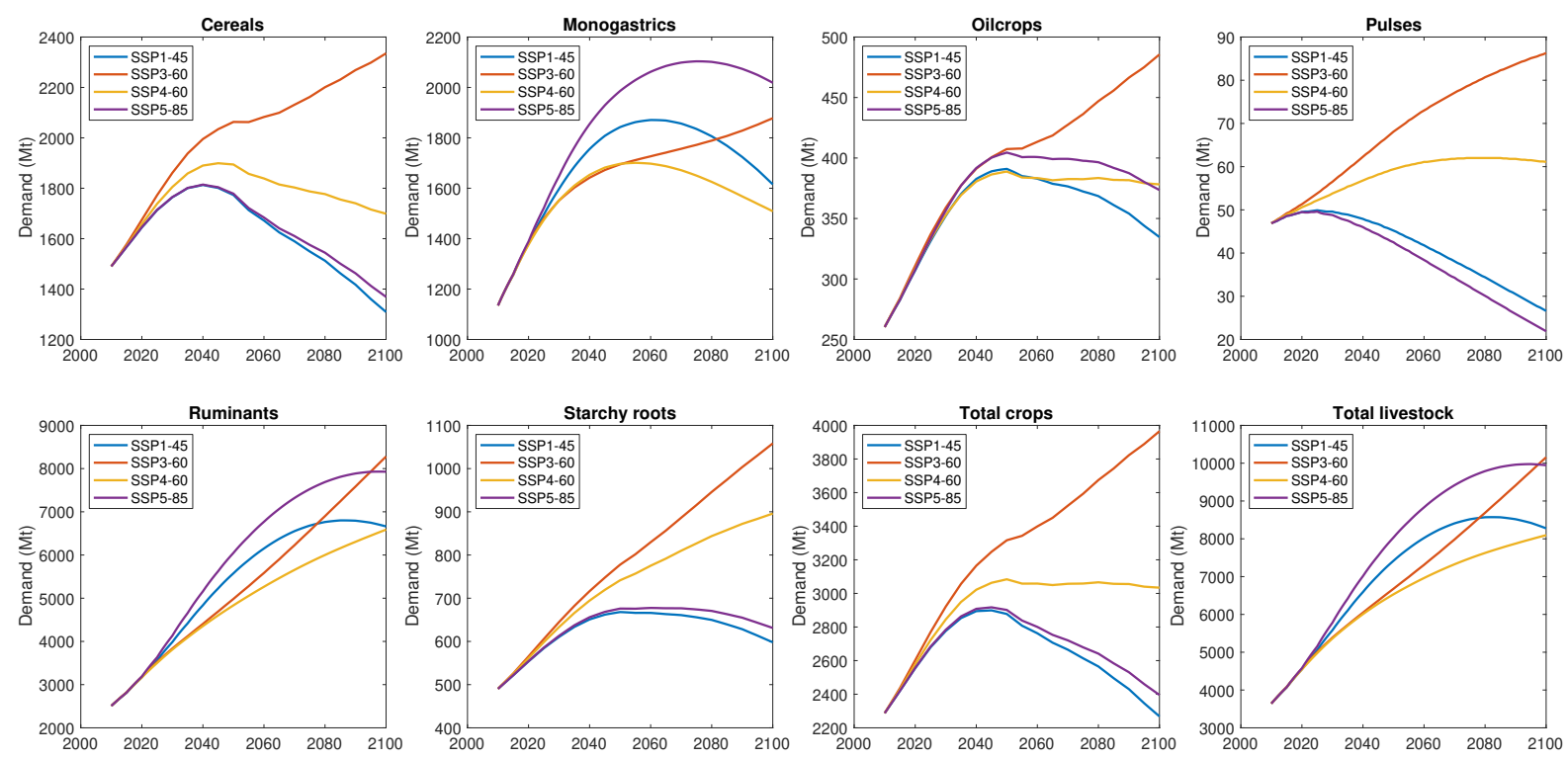

Figure S5. Demand calculated by PLUM for each commodity in each scenario. Demand for livestock (monogastrics, ruminants, and total livestock) is given in terms of feed equivalent. 

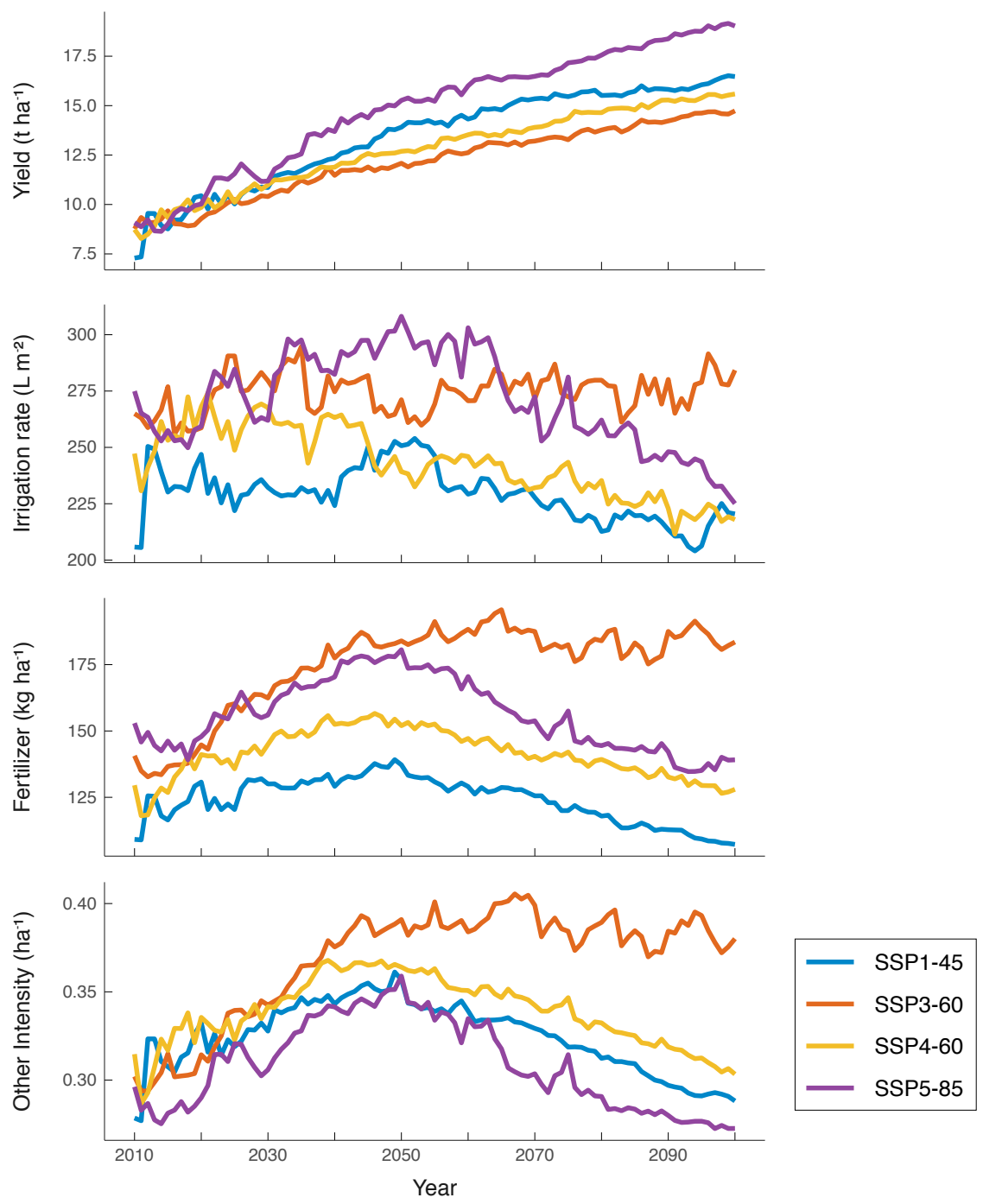

Figure S6. Expected global management inputs and yields calculated by PLUM (before harmonization) for each scenario. Averages per area of cropland. Non-harmonized values at beginning of period do not align because of scenario-specific parameters in PLUM. 


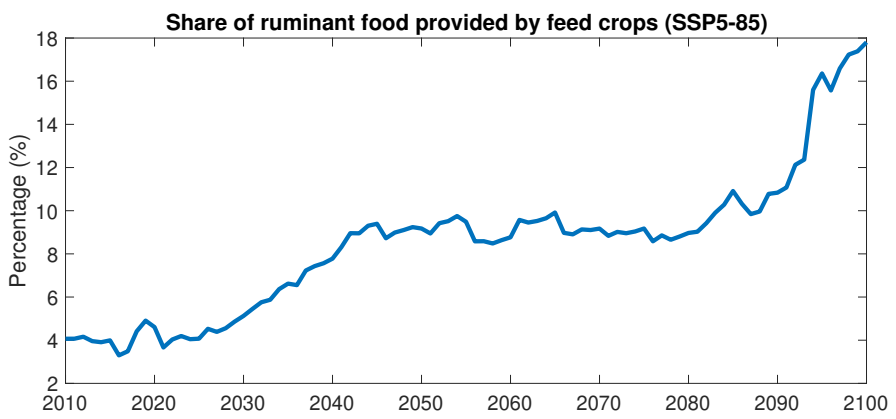

Figure S7. Fraction of SSP5-85 ruminant food demand that is satisfied by feed crops, as opposed to pasture grasses.

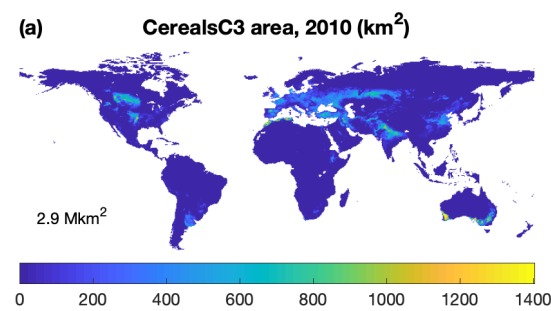

(b) $\quad \Delta$ CerealsC3 area, 2100: SSP1-45 $\left(\mathrm{km}^{2}\right)$

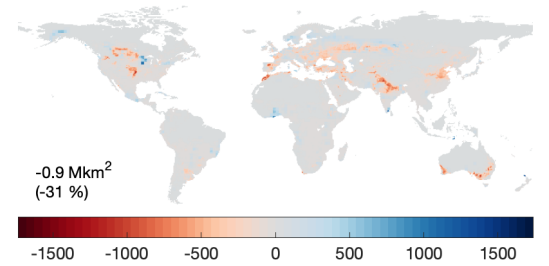

(d)

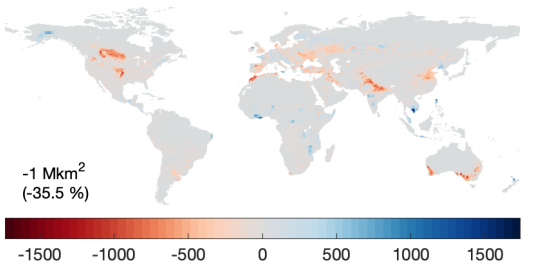

(c) $\quad \Delta$ CerealsC3 area, 2100: SSP3-60 $\left(\mathrm{km}^{2}\right.$

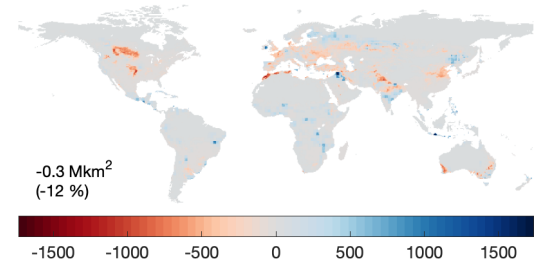

(e) $\triangle$ CerealsC3 area, 2100: SSP5-85 $\left(\mathrm{km}^{2}\right)$

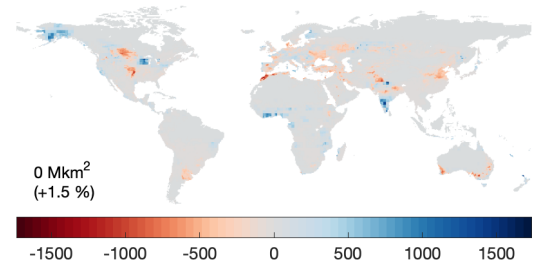

Figure S8. (a) Area of cropland planted with CerealsC3 in 2010 from LUH2. (b-e) Difference between (a) and area in 2100 from PLUM for (b) SSP5-85, (c) SSP3-60, (d) SSP1-45, (e) SSP4-60. 


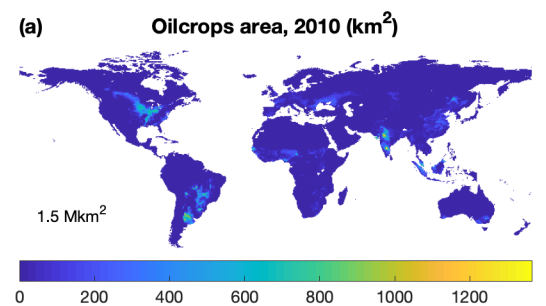

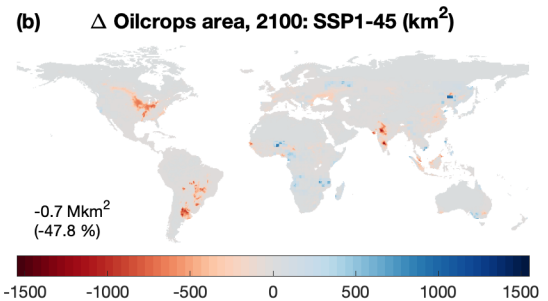

(d) $\quad \Delta$ Oilcrops area, 2100: SSP4-60 $\left(\mathrm{km}^{2}\right)$

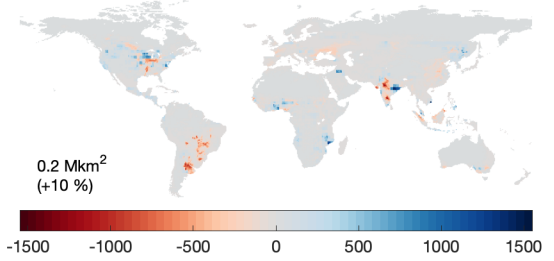

(c) $\quad \Delta$ Oilcrops area, 2100: SSP3-60 $\left(\mathrm{km}^{2}\right)$

(e) $\quad \Delta$ Oilcrops area, 2100: SSP5-85 $\left(\mathrm{km}^{2}\right)$

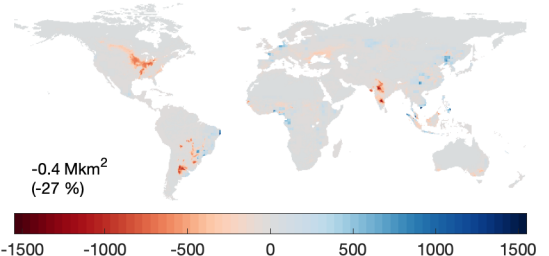

Figure S9. As Figure S8, but for Oilcrops: (a) Area of cropland planted with Oilcrops in 2010 from LUH2. (b-e) Difference between (a) and area in 2100 from PLUM for (b) SSP5-85, (c) SSP3-60, (d) SSP1-45, (e) SSP4-60.
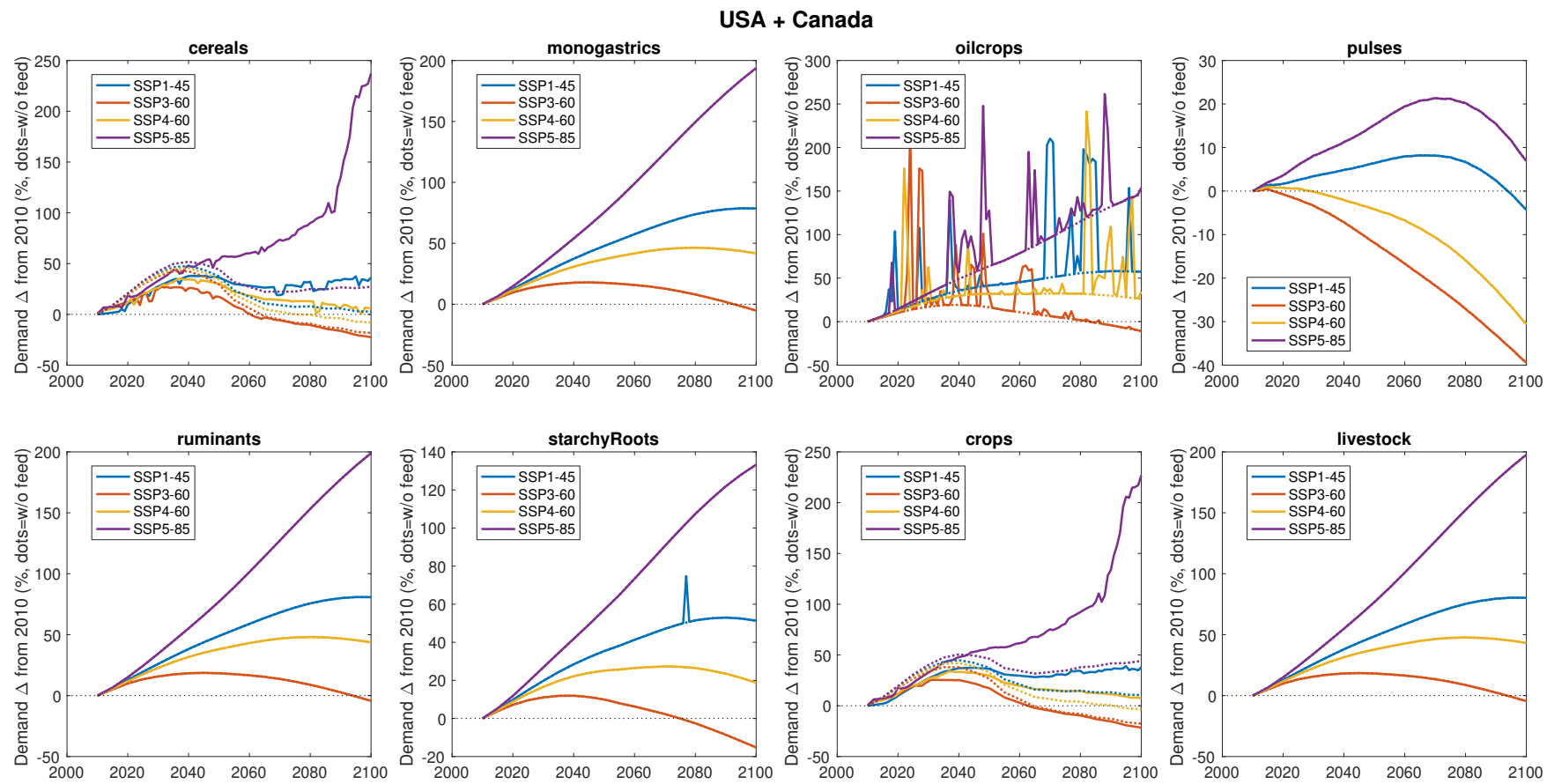

Figure S10. Percentage change in demand in North America (United States and Canada) for commodities and commodity groups in each scenario. Solid lines include all uses; dotted lines exclude feed. 

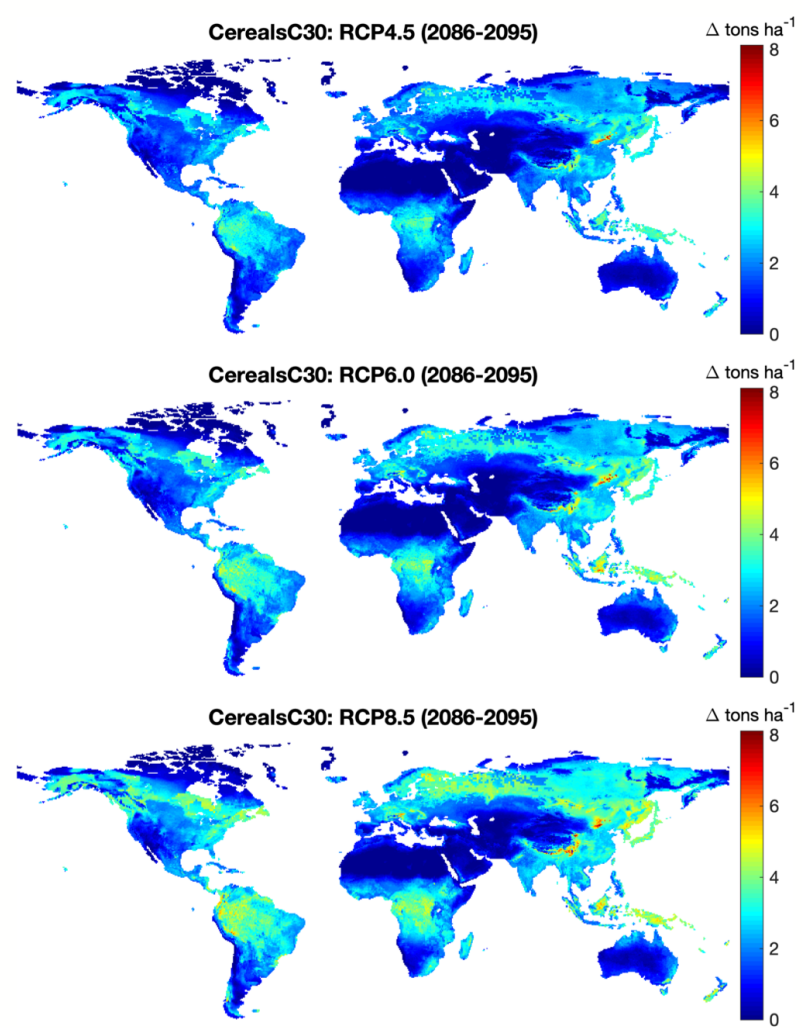
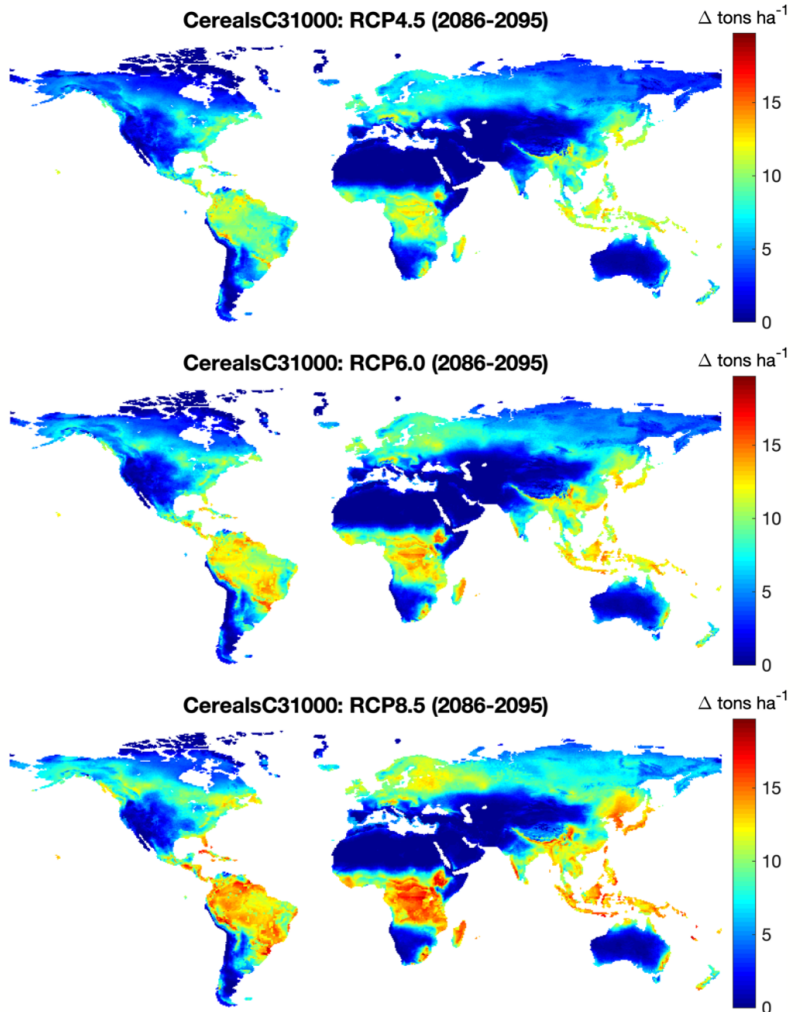

Figure S11. LPJ-GUESS simulated mean yield in 2086-2095 (not including PLUM calibration factors) for rainfed CerealsC3 with (columns) 0 and $1000 \mathrm{kgN} \mathrm{ha}^{-1}$ (rows) in each climate scenario, from yield-generating potential runs. Note different color scales between columns. 
South Asia: Demand and production
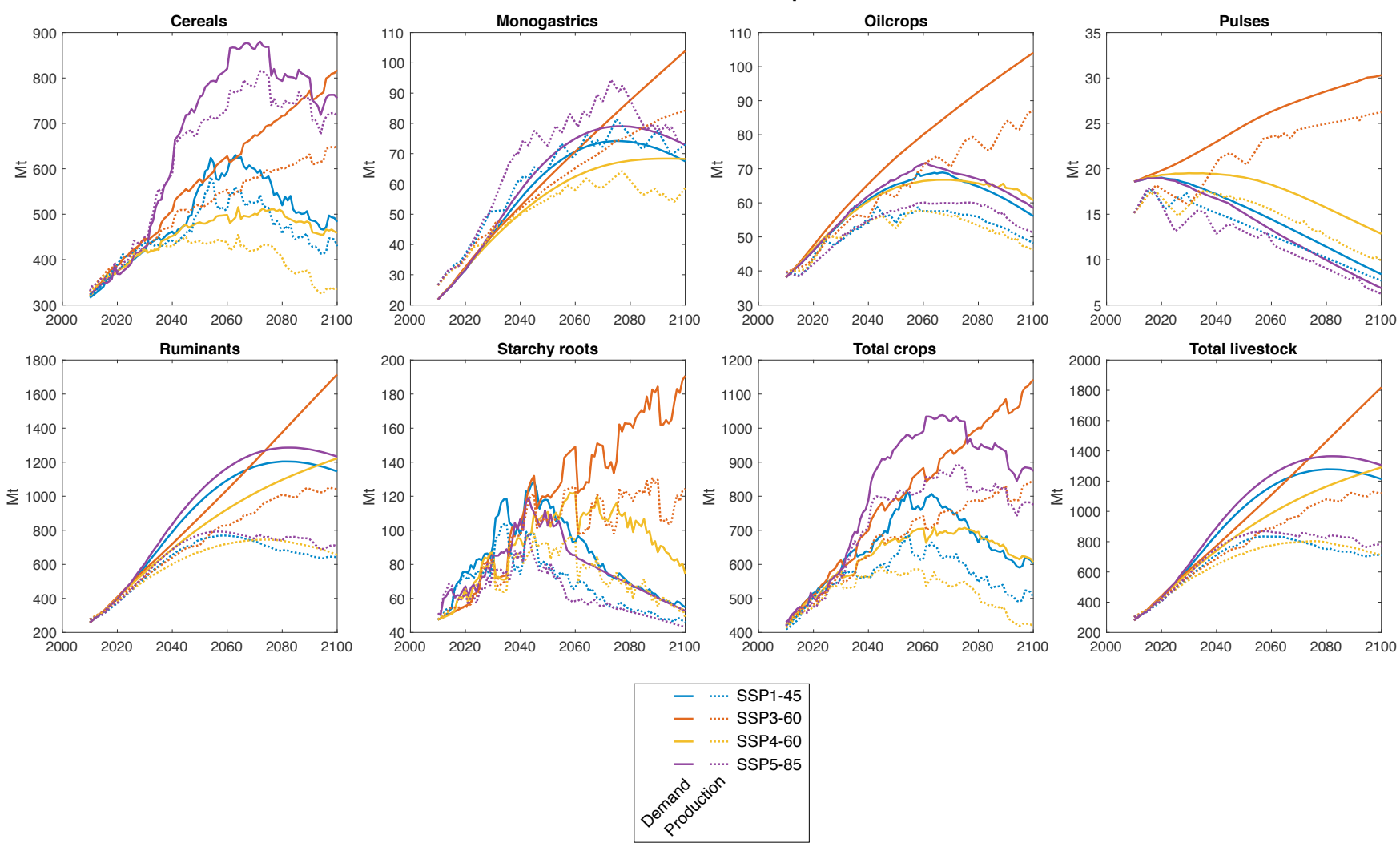

Figure S12. Demand and PLUM-expected domestic production for South Asia (India, Sri Lanka, Pakistan, Afghanistan, Bhutan, and Nepal). 

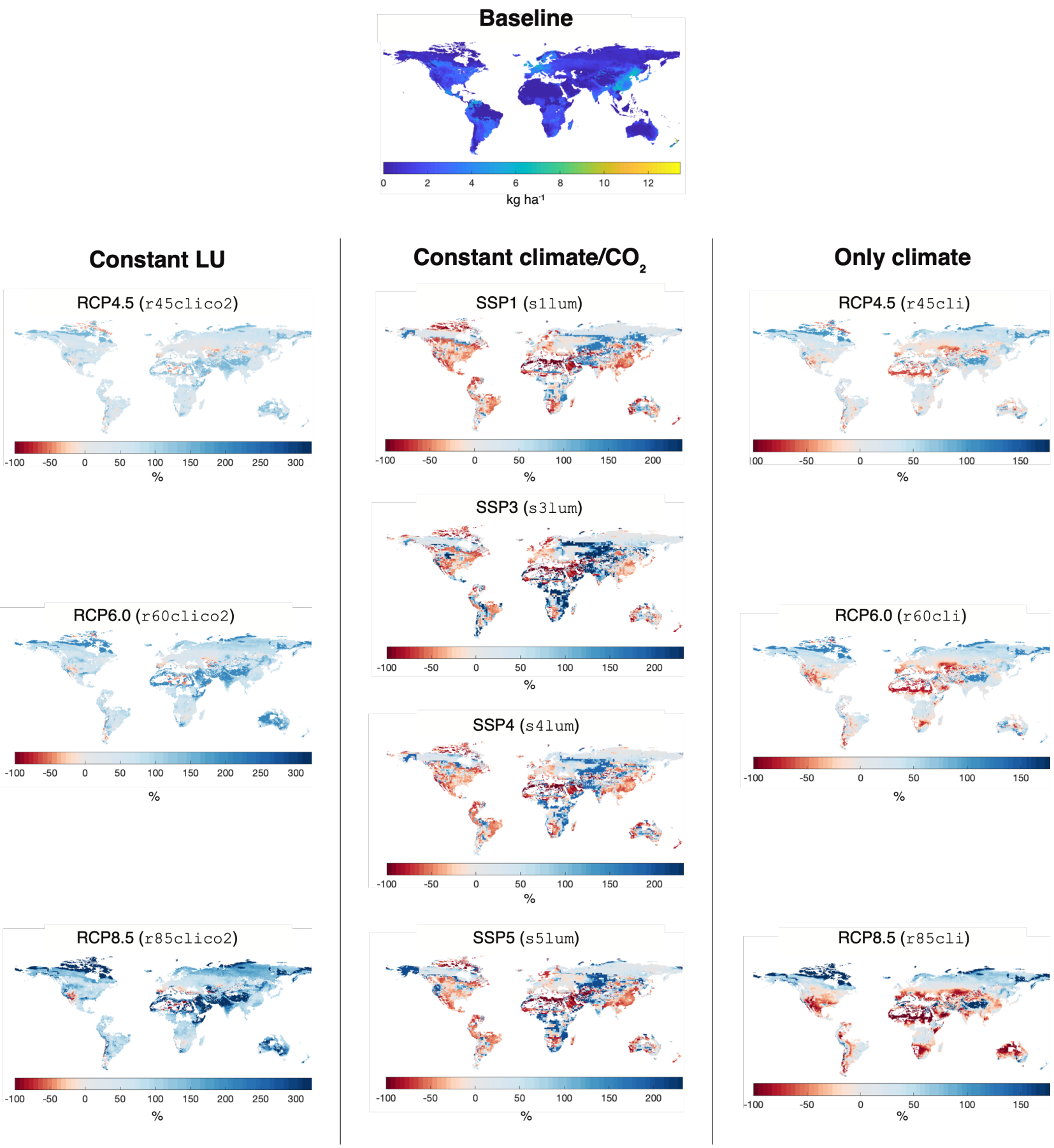

Figure S13. Percent change in mean yield ( $\left.\mathrm{kg} \mathrm{ha}^{-1} \mathrm{yr}^{-1}\right)$ of CerealsC3 from 2001-2010 ("Baseline") to 2091-2100 in Constant-LU (rYYclico2; left), Constant Climate/CO $(s X l u m$; center), and Only Climate ( $r Y Y c l i$; right) experiments for each scenario. Note that color scales differ between columns. 

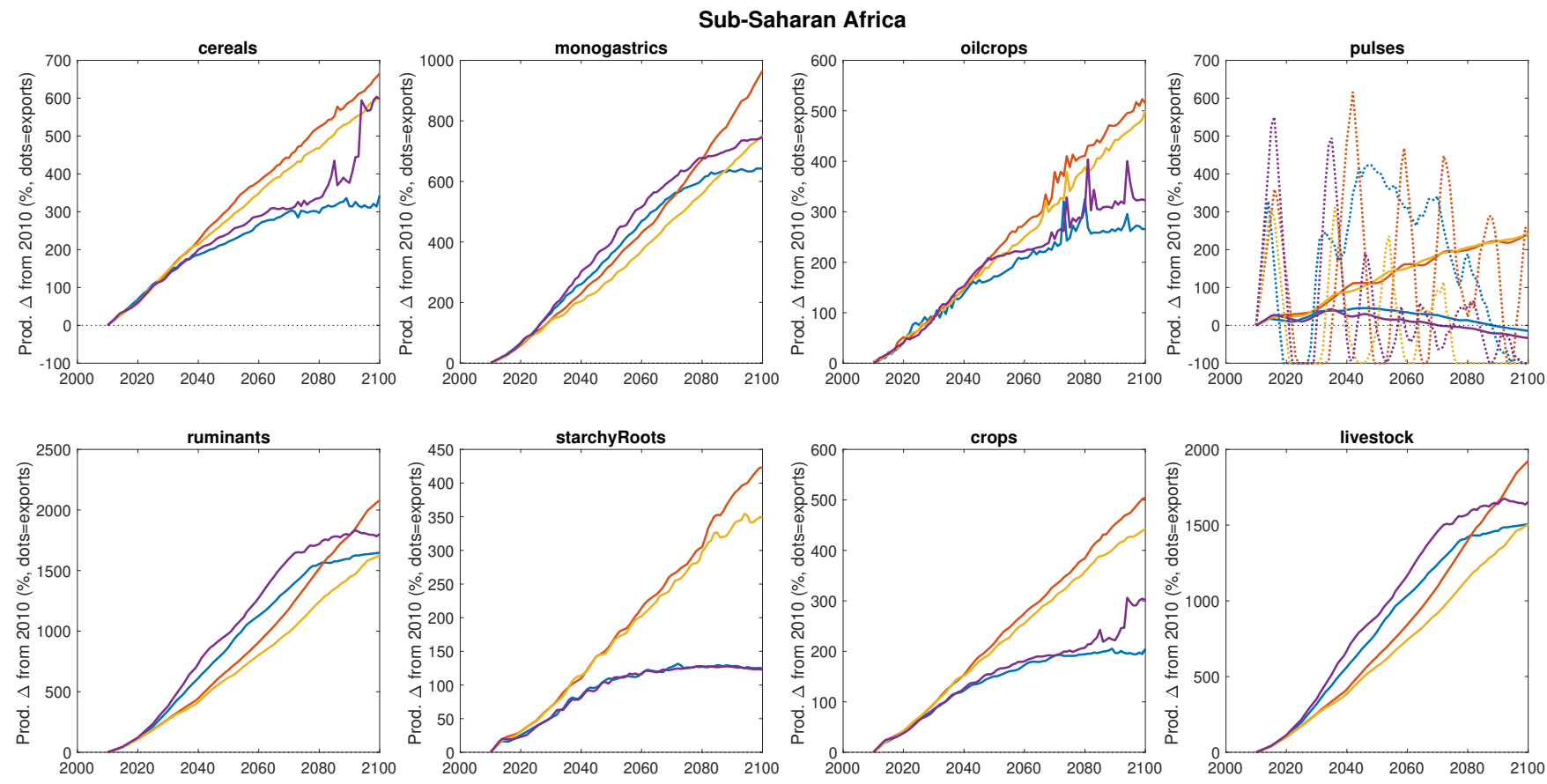

Figure S14. Percentage change in production for commodities and commodity groups in each scenario for Sub-Saharan Africa (Madagascar plus all continental African countries except Algeria, Djibouti, Egypt, Morocco, Libya, and Tunisia). Solid lines include all production; dotted lines represent exports. 

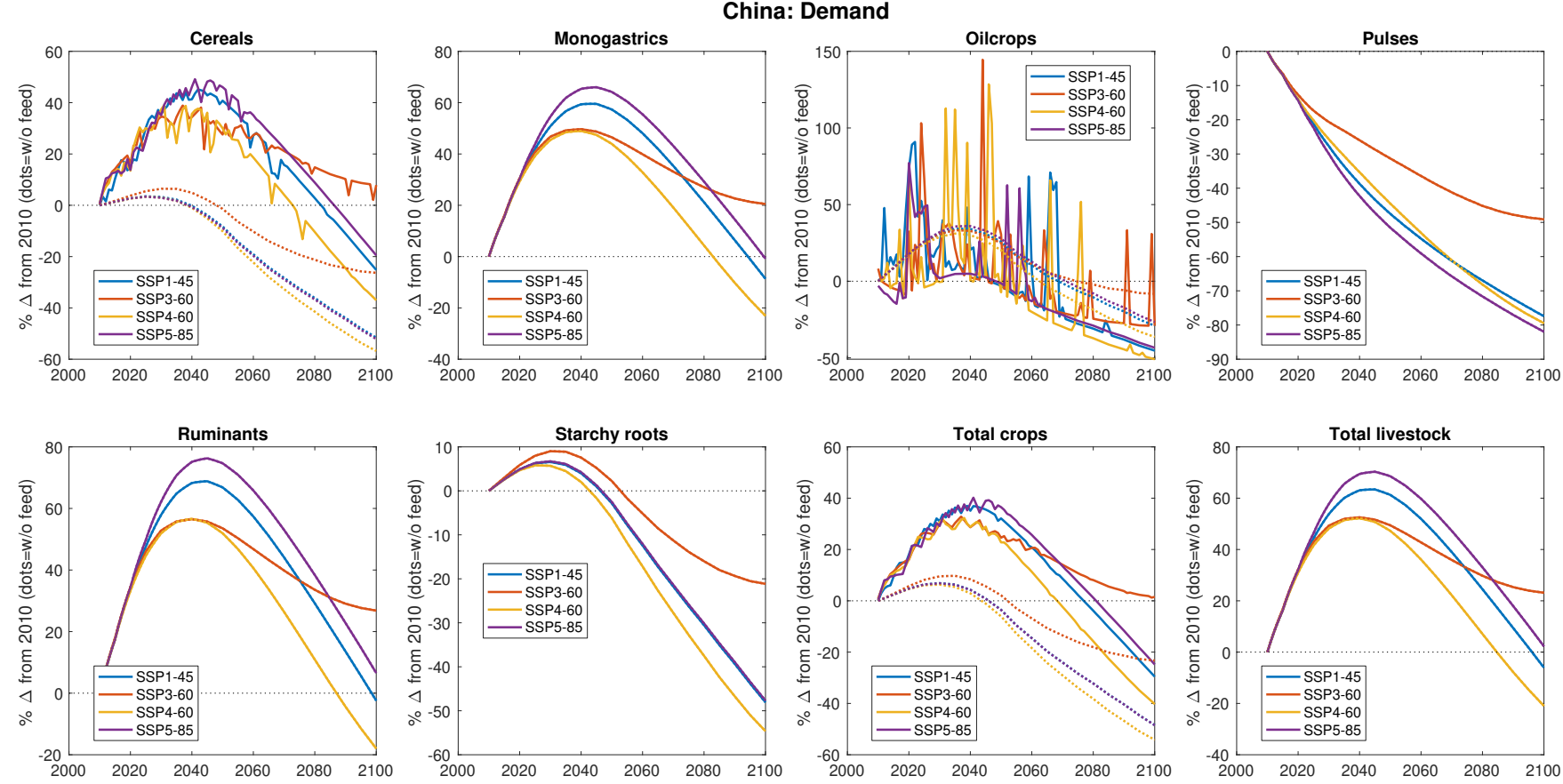

Figure S15. Demand trajectories for China. 
Diff. in vegetation C, 2000s to 2090s

(a) SSP3-60 (s3lum_r60clico2)

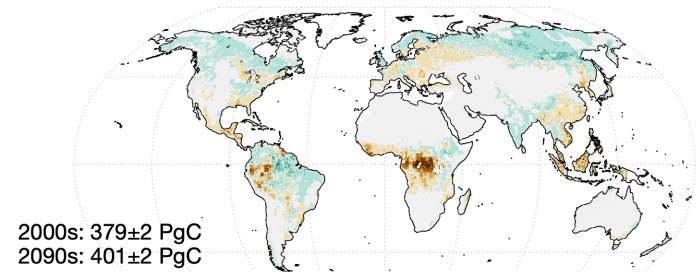

(b)

Const. LU (r60clico2)

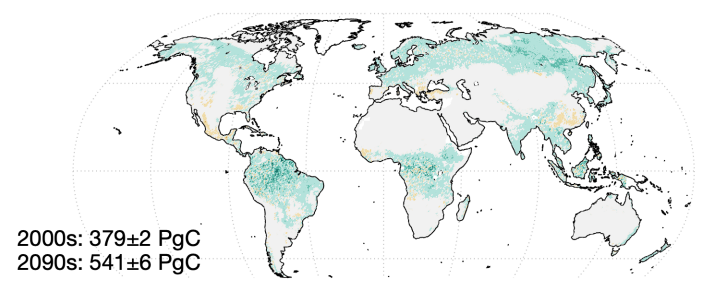

(c)

Const. clim./CO2 (s3lum)

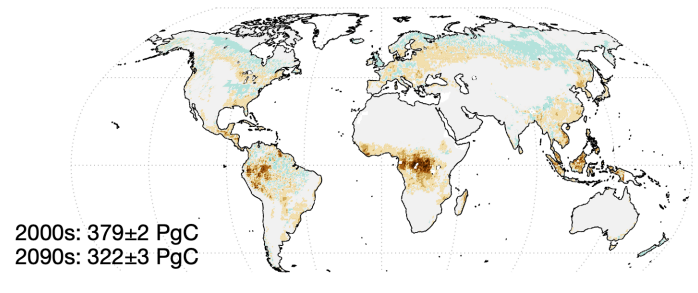

(d)

Const. clim. (s3lum_r60co2)

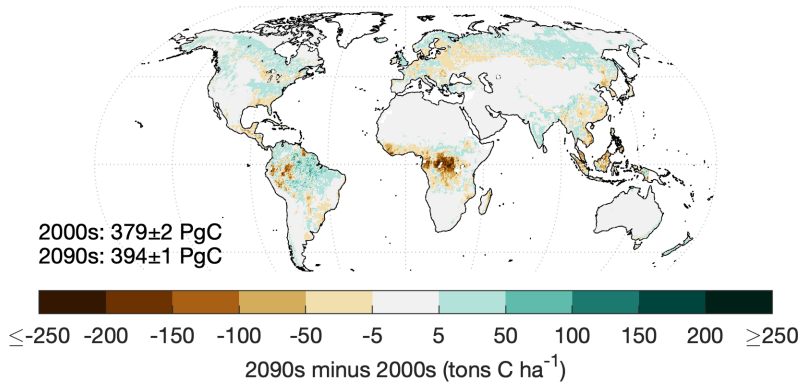

Figure S16. Maps showing difference in mean vegetation carbon between 2001-2010 ("2000s") and 2091-2100 ("2090s") for (a) SSP3-60, (b-e) related experiments with land use, climate, and/or $\mathrm{CO}_{2}$ held constant. Overlaid text provides decadal means and standard deviations. 
Diff. in annual runoff, 2000s to 2090s

(a)

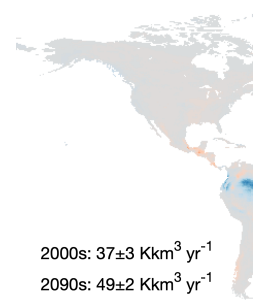

(c)

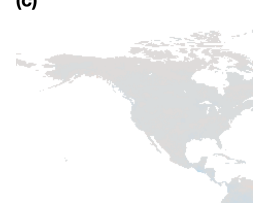

2000s: $37 \pm 3 \mathrm{Kkm}^{3} \mathrm{yr}^{-1}$ 2090s: $39 \pm 3 \mathrm{Kkm}^{3} \mathrm{yr}^{-1}$
SSP5-85 (s5lum_r85clico2)

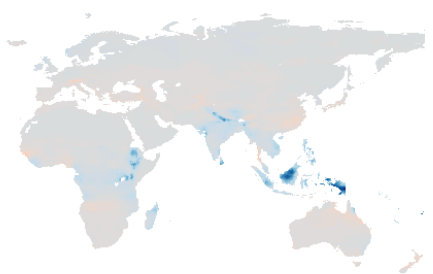

Const. Clim./CO2 (s5lum)

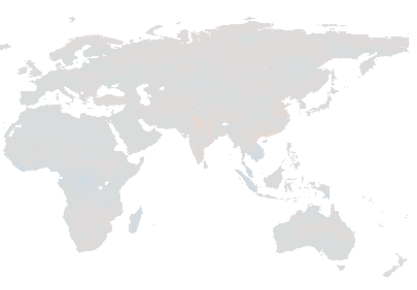

(b)

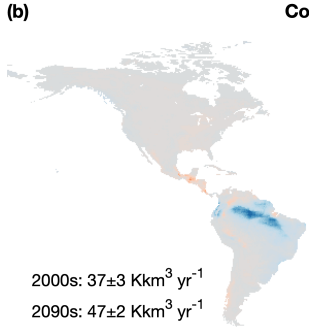

Const. LU (r85clico2)

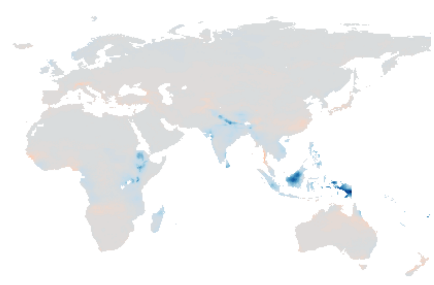

(d)

Const. CO2 (s5lum_r85cli)

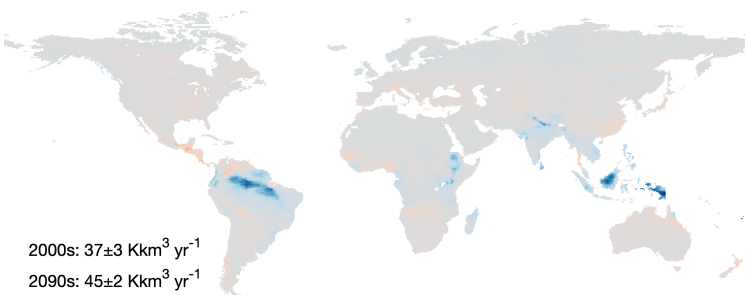

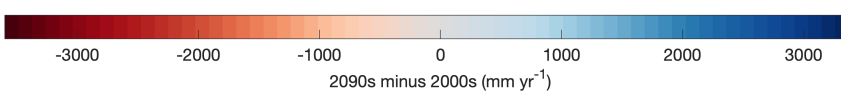

Figure S17. Maps showing difference in mean annual runoff between 2001-2010 (“2000s") and 2091-2100 (“2090s") for (a) SSP5-85, (b-e) related experiments with land use, climate, and/or $\mathrm{CO}_{2}$ held constant. Overlaid text provides decadal means and standard deviations. 


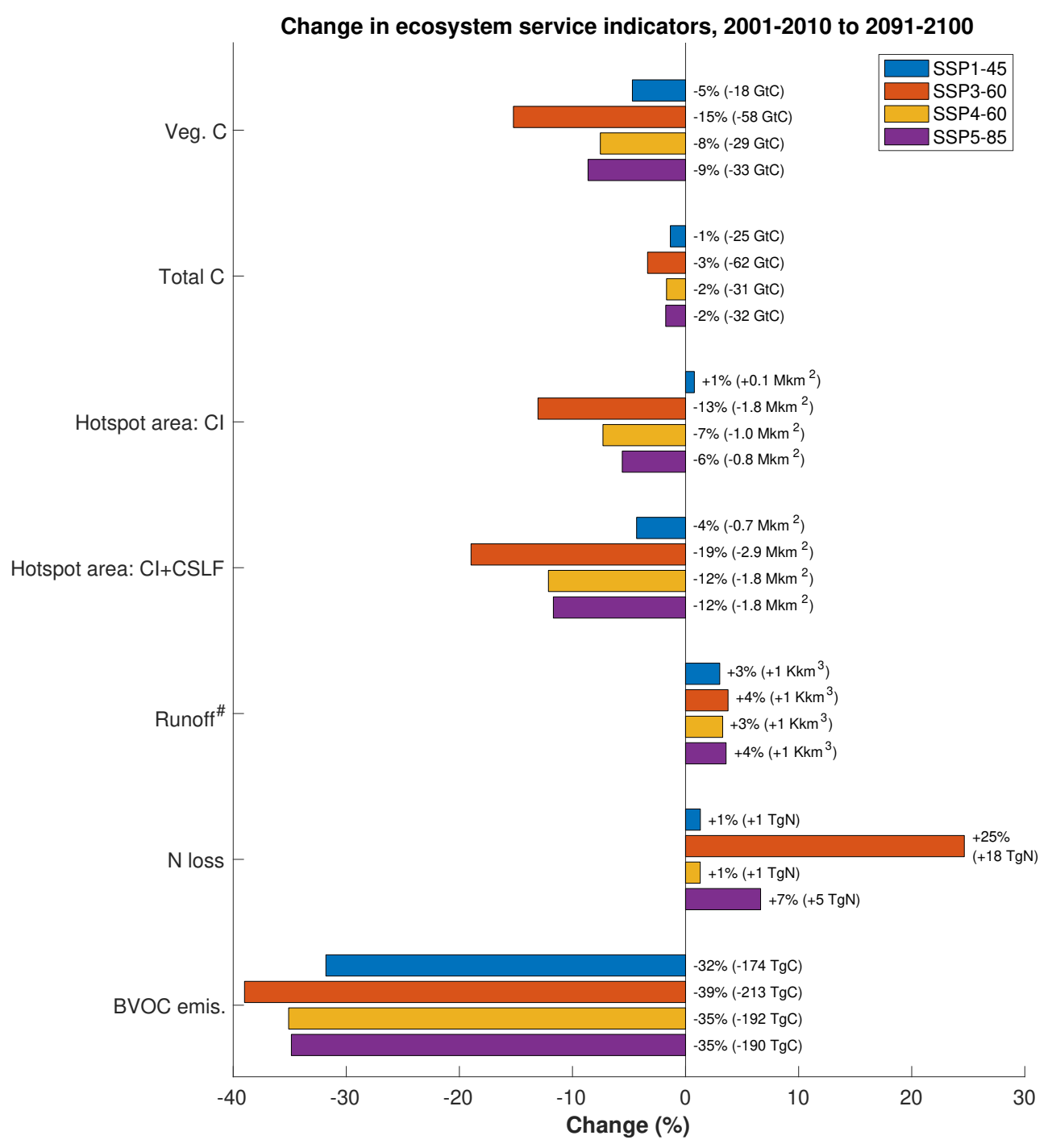

Figure S18. As Figure 4 in main text, but for experiments with climate and $\mathrm{CO}_{2}$ held constant (sXl um): Percent global change in ecosystem service indicators between 2001-2010 and 2091-2100. CSLF: Congolian swamp and lowland forests (see Sect. 3.2.5). ${ }^{\#}$ The time periods compared for runoff were 1971-2000 and 2071-2100 due to high interannual variability. 
(a)

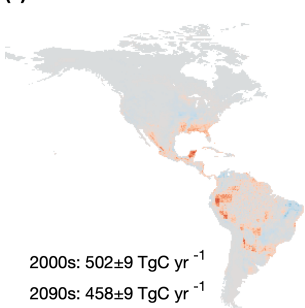

(c)

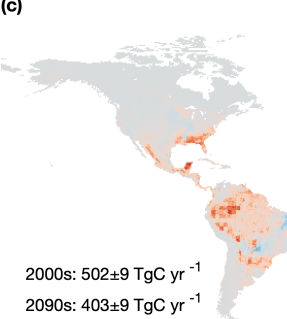

SSP1-45

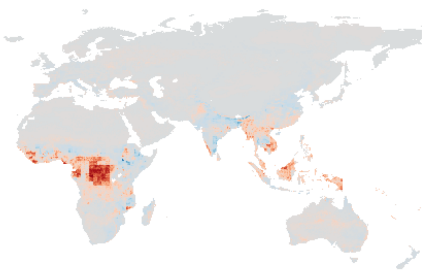

SSP4-60

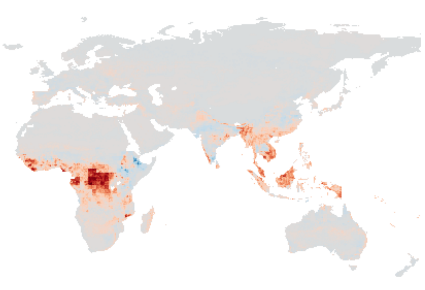

(b)

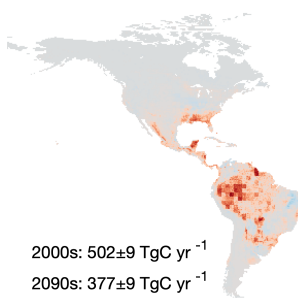

(d)

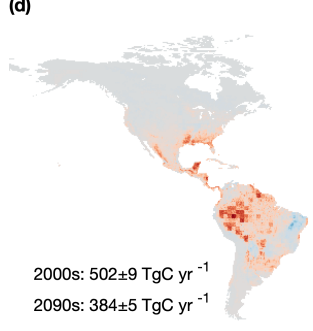

SSP3-60

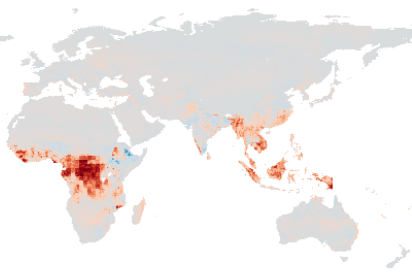

SSP5-85

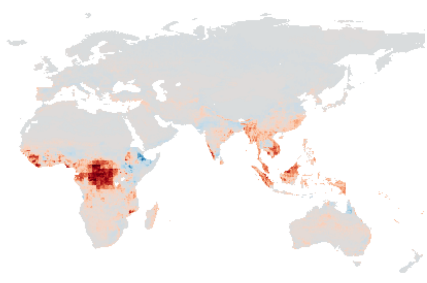

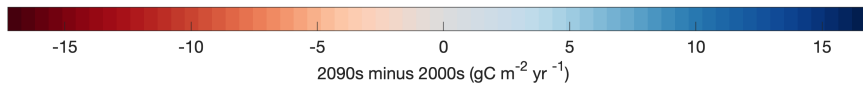

Figure S19. Difference in isoprene emissions $\left(\mathrm{gC} \mathrm{m}^{-2} \mathrm{yr}^{-1}\right)$ between 2001-2010 and 2091-2100 in each scenario.

Diff. in monoterpene emissions, 2000s to 2090s

(a)

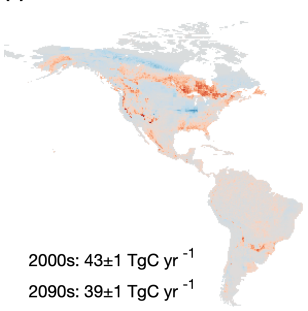

(c)

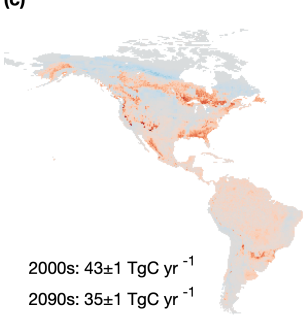

SSP1-45

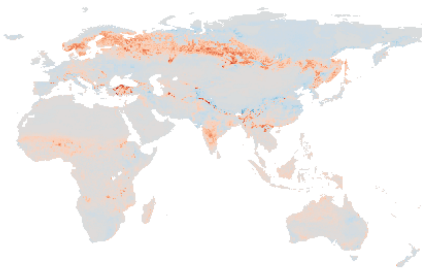

SSP4-60

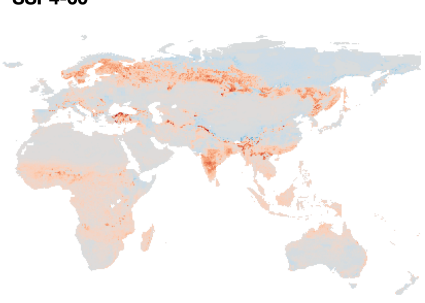

(b)

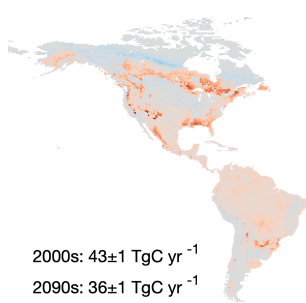

(d)

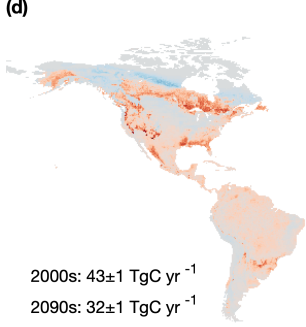

SSP3-60

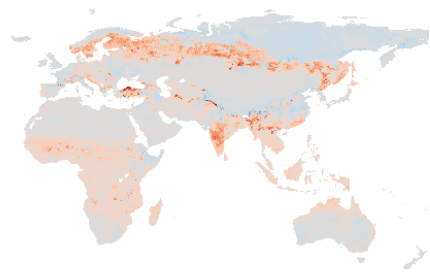

SSP5-85

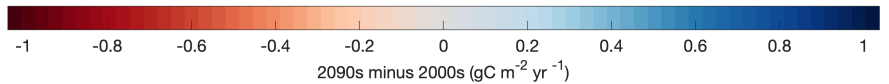

Figure S20. Difference in monoterprene emissions $\left(\mathrm{gC} \mathrm{m}^{-2} \mathrm{yr}^{-1}\right)$ between 2001-2010 and 2091-2100 in each scenario. 


\section{References}

Ahlström, A., Schurgers, G., Arneth, A., and Smith, B.: Robustness and uncertainty in terrestrial ecosystem carbon response to CMIP5 climate change projections, Environmental Research Letters, 7, 044 008-10, 2012.

Alexander, P., Rabin, S. S., Anthoni, P., Henry, R., Pugh, T. A. M., Rounsevell, M. D. A., and Arneth, A.: Adaptation of global land use and management intensity to changes in climate and atmospheric carbon dioxide, Global Change Biology, 24, 2791-2809, 2018.

Dufresne, J. L., Foujols, M. A., Denvil, S., Caubel, A., Marti, O., Aumont, O., Balkanski, Y., Bekki, S., Bellenger, H., Benshila, R., Bony, S., Bopp, L., Braconnot, P., Brockmann, P., Cadule, P., Cheruy, F., Codron, F., Cozic, A., Cugnet, D., de Noblet, N., Duvel, J. P., Ethé, C., Fairhead, L., Fichefet, T., Flavoni, S., Friedlingstein, P., Grandpeix, J. Y., Guez, L., Guilyardi, E., Hauglustaine, D., Hourdin, F., Idelkadi, A., Ghattas, J., Joussaume, S., Kageyama, M., Krinner, G., Labetoulle, S., Lahellec, A., Lefebvre, M. P., Lefevre, F., Levy, C., Li, Z. X., Lloyd, J., Lott, F., Madec, G., Mancip, M., Marchand, M., Masson, S., Meurdesoif, Y., Mignot, J., Musat, I., Parouty, S., Polcher, J., Rio, C., Schulz, M., Swingedouw, D., Szopa, S., Talandier, C., Terray, P., Viovy, N., and Vuichard, N.: Climate change projections using the IPSL-CM5 Earth System Model: from CMIP3 to CMIP5, Climate Dynamics, 40, 2123-2165, 2013.

Elliott, J., Müller, C., Deryng, D., Chryssanthacopoulos, J., Boote, K. J., Büchner, M., Foster, I., Glotter, M., Heinke, J., Iizumi, T., Izaurralde, R. C., Mueller, N. D., Ray, D. K., Rosenzweig, C., Ruane, A. C., and Sheffield, J.: The Global Gridded Crop Model Intercomparison: data and modeling protocols for Phase 1 (v1.0), Geoscientific Model Development, 8, 261-277, 2015.

Engström, K., Olin, S., Rounsevell, M. D. A., Brogaard, S., van Vuuren, D. P., Alexander, P., Murray-Rust, D., and Arneth, A.: Assessing uncertainties in global cropland futures using a conditional probabilistic modelling framework, Earth System Dynamics, 7, 893-915, 2016.

FAOSTAT: Commodity Balances/Crops Primary Equivalent (2018-09-24), Food and Agriculture Organization of the United Nations, 2018a. FAOSTAT: Inputs/Land Use (2018-09-24), Food and Agriculture Organization of the United Nations, $2018 \mathrm{~b}$.

FAOSTAT: Production/Crops (2018-09-24), Food and Agriculture Organization of the United Nations, 2018c.

Harris, I., Jones, P. D., Osborn, T. J., and Lister, D. H.: Updated high-resolution grids of monthly climatic observations - the CRU TS3.10 Dataset, International Journal of Climatology, 34, 623-642, 2014.

Hurtt, G. C., Chini, L. P., Frolking, S., Betts, R. A., Feddema, J., Fischer, G., Fisk, J. P., Hibbard, K., Houghton, R. A., Janetos, A., Jones, C. D., Kindermann, G., Kinoshita, T., Klein Goldewijk, K., Riahi, K., Shevliakova, E., Smith, S., Stehfest, E., Thomson, A., Thornton, P., van Vuuren, D. P., and Wang, Y. P.: Harmonization of land-use scenarios for the period 1500-2100: 600 years of global gridded annual land-use transitions, wood harvest, and resulting secondary lands, Climatic Change, 109, 117-161, 2011.

Le Quéré, C., Andrew, R. M., Canadell, J. G., Sitch, S., Korsbakken, J. I., Peters, G. P., Manning, A. C., Boden, T. A., Tans, P. P., Houghton, R. A., Keeling, R. F., Alin, S., Andrews, O. D., Anthoni, P., Barbero, L., Bopp, L., Chevallier, F., Chini, L. P., Ciais, P., Currie, K., Delire, C., Doney, S. C., Friedlingstein, P., Gkritzalis, T., Harris, I., Hauck, J., Haverd, V., Hoppema, M., Klein Goldewijk, K., Jain, A. K., Kato, E., Körtzinger, A., Landschützer, P., Lefèvre, N., Lenton, A., Lienert, S., Lombardozzi, D., Melton, J. R., Metzl, N., Millero, F., Monteiro, P. M. S., Munro, D. R., Nabel, J. E. M. S., Nakaoka, S.-i., O amp apos Brien, K., Olsen, A., Omar, A. M., Ono, T., Pierrot, D., Poulter, B., Rödenbeck, C., Salisbury, J., Schuster, U., Schwinger, J., Séférian, R., Skjelvan, I., Stocker, B. D., Sutton, A. J., Takahashi, T., Tian, H., Tilbrook, B., van der Laan-Luijkx, I. T., van der Werf, G. R., Viovy, N., Walker, A. P., Wiltshire, A. J., and Zaehle, S.: Global Carbon Budget 2016, Earth System Science Data, 8, 605-649, 2016.

Portmann, F. T., Siebert, S., and Döll, P.: MIRCA2000—Global monthly irrigated and rainfed crop areas around the year 2000: A new high-resolution data set for agricultural and hydrological modeling, Global Biogeochemical Cycles, 24, GB1011, 2010.

Rabin, S. S.: Harmonizing LandSyMM with historical data, p. 3, 2019.

Rosenzweig, C., Jones, J. W., Hatfield, J. L., Ruane, A. C., Boote, K. J., Thorburn, P., Antle, J. M., Nelson, G. C., Porter, C., Janssen, S., Asseng, S., Basso, B., Ewert, F., Wallach, D., Baigorria, G., and Winter, J. M.: The Agricultural Model Intercomparison and Improvement Project (AgMIP): Protocols and pilot studies, Agricultural and Forest Meteorology, 170, 166-182, 2013.

Taylor, K. E., Stouffer, R. J., and Meehl, G. A.: An Overview of CMIP5 and the Experiment Design, Bulletin of the American Meteorological Society, 93, 485-498, 2012.

Viovy, N.: CRUNCEP Version 7: Atmospheric Forcing Data for the Global Carbon Budget 2016, 2016.

Zhang, B., Tian, H., Lu, C., Dangal, S. R. S., Yang, J., and Pan, S.: Manure nitrogen production and application in cropland and rangeland during 1860-2014: A 5-minute gridded global data set for Earth system modeling, Earth System Science Data Discussions, pp. 1-35, 2017a.

Zhang, B., Tian, H., Lu, C., Dangal, S. R. S., Yang, J., and Pan, S.: Global manure nitrogen production and application in cropland during 1860-2014: a 5 arcmin gridded global dataset for Earth system modeling, Earth System Science Data, 9, 667-678, 2017b. 